\title{
A arqueologia da tradução de cantos Tupi- Guarani no Brasil
}

\author{
Helena Lúcia Silveira Barbosa*
}

Há um imenso universo poético representado pelos cantos ameríndios ainda hoje pouco conhecido e estudado no campo da tradução musical. Eles vêm sendo traduzidos para o português de forma crescente desde a década de 1970, quando a documentação das tradições orais começou a ser realizada de maneira mais organizada e um maior número de estudiosas/os interessadas/os no tema surgiu desde então.

O presente artigo é uma investigação sobre a história da tradução de cantos Tupi-Guarani das últimas cinco décadas. A pesquisa desenvolveu-se em duas etapas. A primeira etapa foi direcionada para a realização de um levantamento dos textos de partida em línguas Tupi-Guarani e suas respectivas traduções, fontes primárias principais, bem como de fontes extratextuais presentes nas publicações em que as traduções estão inseridas, como comentários sobre os cantos e seu processo tradutório, notas biográficas das/os e sobre tradutoras e tradutores, informações bibliométricas, entre outras relevantes para a pesquisa. Esse levantamento serviu de base para a construção de um corpus de cantos Tupi-Guarani traduzidos para o português. Em posse de todo esse material, foi dado início à segunda etapa da investigação, focada na construção de um mapeamento dessas traduções e de suas/seus tradutoras/es a partir do que Anthony Pym denominou como "arqueologia da tradução", método que tem a intenção de responder: "quem traduziu o que, como, onde, quando, para quem e com que efeito" (1998, p. 5). O intuito deste trabalho é mostrar como a arqueologia da tradução possui um grande potencial para o

* Mestra em Estudos da Tradução pela Universidade de São Paulo (USP). 
desenvolvimento de uma história da tradução de cantos Tupi-Guarani no Brasil, recuperando informações sobre essas textualidades e seus sujeitos tradutores, comumente negligenciados nas narrativas historiográficas tradicionais contidas na história da tradução brasileira. Ainda, essa metodologia, aliada ao uso de gerenciadores de referência bibliográfica, pode ser extremamente eficiente para lidar com um corpus bibliográfico de grande extensão, tendo em vista que possibilita a extração de grandes quantidades de dados e, consequentemente, a construção de um mapeamento em larga escala do cenário estudado.

O estudo e a prática da tradução de cantos ameríndios - na verdade, das artes de expressão ameríndias como um todo - situam-se ainda em uma posição marginal nos Estudos da Tradução quando comparados a gêneros musicais de certa forma "canonizados" e com maior tradição. Pouco se sabe sobre o que tem de fato sido traduzido e por quem, sobre as especificidades dessas artes e os desafios que apresentam em termos linguísticos e ontológicos. Ainda não dispomos de teorizações sobre estratégias de tradução, nem de uma historiografia propriamente dita, que é ainda incipiente e em vias de construção.

Há uma urgência em se dar lugar e voz a este tipo de produção tradutória e aos seus respectivos sujeitos tradutores. As últimas décadas experienciaram um aumento significativo de publicações não só de cantos, mas também de narrativas e outros tipos de artes indígenas da palavra, sem falar na atual proliferação da produção de textos escritos por indígenas em razão do avanço da educação escolar indígena (MATOS, 2011), o que se apresenta como uma oportunidade de se refletir sobre como a experiência da poética indígena pode afetar nossos conceitos sobre escrita, poesia e literatura. Abrir a percepção à complexidade desses textos e abrir os ouvidos às vozes que ressoam neles é o que sugere Cláudia Neiva de Matos (2011, p. 7). Adotar uma postura de não folclorizar as artes verbais indígenas, orais ou escritas, mas de recepcioná-las de uma forma crítica tal que se deixe afetar esteticamente por elas. A proposta é criar uma situação dialogal e não a da observação distanciada. As textualidades estranhas ao cânone literário ocidental ainda estão situadas em um lugar de tensão entre aqueles que optam por abordá-las de forma estética ou de forma antropológica. Entretanto, estes esforços ainda são raros e pouco discutidos no campo das Letras, mesmo pelos estudiosos das literaturas orais. 
É com o intuito de estreitar esta lacuna que a presente pesquisa foi realizada. Mesmo constituindo apenas uma fração de um imenso universo de cantos ameríndios a ser explorado, seu propósito maior é fornecer uma base de dados ampla em termos linguístico e temporal, bem como abrir portas para futuras teorizações sobre a prática da tradução de cantos Tupi-Guarani a partir da "arqueologia" realizada. Este é um tema que tem muito a oferecer para a história da tradução no Brasil, tendo em vista sua historicidade e as possibilidades que apresentam sobre outros modos de se produzir história.

\section{A arqueologia da tradução}

Em Method in Translation History (1998), Anthony Pym afirma que a história da tradução pode ser dividida em pelo menos três áreas: "arqueologia", "crítica" e "explicação" (esta última assim denominada por falta de um termo melhor, segundo o autor).

A arqueologia da tradução pode ser definida como

[...] um conjunto de discursos que têm como objetivo responder, no todo ou em parte, a complexa questão: 'quem traduziu o que, como, onde, quando, para quem e com qual efeito?'. Pode incluir qualquer coisa, desde a compilação de catálogos até a realização de pesquisas biográficas sobre tradutoras e tradutores. O termo 'arqueologia' não é utilizado aqui de forma pejorativa, nem implica uma revelação de ordem foucaultiana. Simplesmente denota uma área fascinante, que normalmente envolve um complexo trabalho de detetive, imenso autossacrifício e um grande serviço prestado a outras áreas da história da tradução ${ }^{12}$ (PYM, 1998, p. 5).

Sendo assim, é a área que se dedica à escavação do material de pesquisa e de investigação de suas características, das mais gerais às mais específicas e pontuais. Grosso modo, destina-se, principalmente, à produção de listas, conforme Pym (1998, p. 7).

\footnotetext{
${ }^{1}$ Translation archaeology is a set of discourses concerned with answering all or part of the complex question 'who translated what, how, where, when, for whom and with what effect?'. It can include anything from the compiling of catalogues to the carrying out of bibliographical research on translators. The term 'archaeology' is not meant to be pejorative here, nor does it imply any particularly Foucauldian revelations. It simply denotes a fascinating field that often involves complex detective work, greatsacrifice and very real service to other areas of translation history.

${ }^{2}$ Essa e outras traduções presentes neste artigo são minhas, a não ser que eu indique o contrário.
} 
A crítica histórica, por sua vez, contempla o conjunto de discursos direcionados à parte filológica da historiografia, à construção de análises e argumentos. Já a explicação é a área que busca responder por que artefatos arqueológicos ocorrem onde ocorrem, como ocorrem e no momento em que ocorrem; é a parte da pesquisa histórica focada em discutir os processos de mudança e em construir a narrativa histórica propriamente dita. Pensando a partir do fato histórico em si, a arqueologia e a crítica histórica estão relacionadas a fatos e textos, enquanto a explicação relaciona-se à causalidade existente entre esses fatos e textos, mais especificamente à causalidade que perpassa relações de poder (PYM, 1998, p. 6).

Apesar de corresponderem a três áreas distintas, toda história da tradução construída envolve ou presume discursos advindos de todas elas.

[...] não há crítica ou explicação sem dado arqueológico, nem explicação sobre processos de mudança sem alguma ideia sobre os valores envolvidos em tal mudança. [...] nenhuma dessas três partes podem assumir independência epistemológica em relação às outras. Qualquer pessoa desenvolvendo história da tradução está, em algum nível, envolvida nas três atividades (não há um discurso puramente 'informativo' ou 'descritivo', assim como não é possível fazer qualquer especulação abstrata sem ter pelo menos alguma base de natureza arqueológica) (PYM, 1998, p. 6).

Considerando o campo de estudos relativo à tradução de cantos ameríndios, pouco trabalho arqueológico foi feito até hoje, razão pela qual decidimos nos dedicar à fundo a esta primeira parte da pesquisa histórica ao invés de abordar um ou outro canto em específico e tecer construções que não possibilitariam chegar a maiores generalizações de natureza histórica. Para se compreender como se dá a atividade da tradução desses cantos no Brasil, suas especificidades, quem são os sujeitos envolvidos e se desenvolver uma teoria da tradução ameríndia, é preciso primeiramente estar munida/o de um material consistente que possibilite tais análises e desenvolvimentos teóricos. Ainda, com um corpus tão extenso quanto o que foi construído (total de 233 traduções), acreditamos que seria mais frutífero realizar um mapeamento geral que mostrasse a diversidade de traduções Tupi-Guarani existentes e a potência que este campo de estudos pode adquirir. Nossa intenção, assim, foi fornecer a pesquisadores uma base de dados substancial para que a crítica e a explicação 
possam, finalmente, ganhar força na pesquisa sobre a tradução de cantos indígenas e elaborar reflexões e teorizações em maior escala do que simplesmente em estudos de caso pontuais. A crítica e a explicação requerem a arqueologia.

A metáfora de Pym é muito feliz para designar este trabalho que acontece nos bastidores, de pura investigação, que é tão essencial para as outras áreas dos estudos históricos em tradução. $\mathrm{O}$ desenvolvimento que faz do conceito por meio de exemplos de pesquisas arqueológicas em tradução ajuda bastante a entender sobre a profundidade da atividade, bem como sobre seus limites. Entretanto, o autor não dá maiores descrições em termos metodológicos sobre como responder à fórmula base de sua arqueologia; não fala em que cada um dos elementos, de fato, consiste.

Lieven D'hulst, por outro lado, oferece uma boa descrição desses elementos nos artigos Why and How to Write Translation Histories? (2001) e Translation History (2010). Em ambos, traz uma apresentação do campo de estudos da história da tradução e faz uma série de sugestões de objetos de pesquisa em tradução utilizando o que denomina de loci circunstanciais (seus elementos são praticamente os mesmos da fórmula de Pym). O autor baseia-se no método que Quintiliano, Cícero e outros utilizaram para abordar a oratória, o qual tornou-se popular entre oradoras/es e estudiosas/os de retórica com o passar do tempo. O autor francês do século XII Mateus de Vendôme, em seu estudo sobre a arte da poesia ou versificação (Ars versificatoria 1175, I, 116 apud PYM, 2010, p. 399), converteu o método retórico na seguinte fórmula: quem (quis); o que (quid); onde (ubi); por quais meios (quibus auxiliis), por que (cur); como (quomodo); quando (quando); e com qual função (cui bono) (PYM, 2010, p. 399-403).

A fórmula descrita por Mateus de Vendôme passou a ocupar um papel importantíssimo na cultura medieval, sendo usado, inclusive, como um método exegético para a interpretação de textos. Tornou-se bem conhecido e passou a ser muito utilizado em outras áreas do conhecimento, como no jornalismo e no direito criminal, com o objetivo de produzir e agrupar ideias, hipóteses e 
argumentos (PYM, 2010, p. 399). No campo dos Estudos da Tradução, foi utilizado no desenvolvimento da teoria funcionalista ${ }^{3}$.

Seguindo, então, a proposta de Mateus de Vendôme, D’hulst formula possíveis objetos de pesquisa histórica pensando a partir de cada um desses loci circunstanciais, mas aplicando-os aos Estudos da Tradução. Ao utilizar o hexâmetro de Mateus de Vendôme, D'hulst cria um eixo transversal dos estudos históricos da tradução, englobando teoria, processo, crítica, ensino, entre outros. Neste ponto, diverge do que foi proposto por James Holmes em seu clássico mapa disciplinar (HOLMES, 2004 [1972]), criado para descrever e situar as diferentes atividades acadêmicas no âmbito dos Estudos da Tradução.

D'hulst afirma que Holmes insere os estudos relacionados à história da tradução no ramo dos estudos descritivos orientados para o produto ${ }^{4}$, área de pesquisa que se dedica à descrição de traduções existentes, voltando-se especificamente para o texto em si. Ele critica o enquadramento restrito que Holmes dá à história da hradução em seu mapa e dá uma nova perspectiva a este campo de estudos:

O famoso modelo criado para os Estudos da Tradução por James Holmes (HOLMES, 1988; veja também TOURY, 1995, p. 9-19), no qual os "Estudos Históricos da Tradução" fazem parte do ramo dos Estudos Descritivos da Tradução orientados para o produto, é um exemplo da situação de inferioridade da pesquisa histórica: não admite o fato de que pontos de vista históricos podem ser aplicados a todo um conjunto de atividades acadêmicas que lidam com a tradução, incluindo atividades orientadas para o processo e para a função, bem como em teorias da tradução e até em pesquisas aplicadas, como aquelas relacionadas à crítica e à formação de tradutores ${ }^{5}$ (D'HULST, 2010, p. 398-399).

\footnotetext{
${ }^{3}$ Sua aplicabilidade no campo da tradução foi discutida por Reiss, Bühler, Hönig e Nord. Christiane Nord, por exemplo, em Text Analysis and Translation: Theory, Method, and Didactic Application of a Model for Translation-Oriented Text Analysis (1991), faz uso da "Fórmula Q".

4"[...] um dos objetivos finais dos Estudos Descritivos da Tradução poderia ser uma história geral da tradução - independentemente de quão ambicioso tal objetivo possa soar neste momento" / "[...] one of the eventual goals of product-oriented DTS might possibly be a general history of translation - however ambitious such a goal may sound at his time." (HOLMES, 2004 [1972], p. 177).

5“James Holmes's famous model of Translation Studies (J. Holmes 1998; see also G. Toury 1995:9-19), in which 'Historical Translation Studies' was part of product-oriented 'Descriptive Translation Studies', is a token of the Cinderella situation of historical research: it does not acknowledge the fact that historical viewpoints may be applied to the entire set of scholarly activities dealing with translation, thus including process and function oriented activities, as well as translation theories and even applied forms of research such as criticism or training."
} 
Nesse sentido, D’hulst amplia a noção de história da tradução para além dos estudos descritivos, possibilitando o desenvolvimento de uma série de análises que estão na interação da historiografia com a teoria, a crítica, a didática e assim por diante.

Chamamos a atenção para o fato de que a visão de Holmes sobre os Estudos da Tradução era essencialmente voltada para o texto ${ }^{6}$. Outros elementos, como o sujeito tradutor e a própria história da tradução, acabaram por ter uma posição secundária em seu modelo; Pym, por exemplo, aponta para a ausência da pesquisa histórica no mapa como uma área unificada (PYM, 1998, p. 1). Entretanto, em 1972, época em que Holmes publicou seu mapa disciplinar pela primeira vez, a história da tradução ainda não tinha despontado como uma área sólida de estudos e pesquisas - inclusive, não havia consenso nem sobre o nome, o escopo ou a estrutura da disciplina Estudos da Tradução, sendo Holmes o responsável por estabelecer os primeiros passos neste sentido; tal fato deve ser levado em consideração.

De qualquer forma, este novo olhar transversal conferido por Lieven D'hulst ao mapa de Holmes tendo como ponto central a história da tradução é extremamente enriquecedor e abre possibilidades interessantes quanto a objetos de pesquisas, problemáticas e métodos.

Um outro ponto cabe ser destacado quanto à posição que o sujeito tradutor (o elemento quem) ocupa nas "fórmulas metodológicas" de Pym e D'hulst. Pym a constrói a partir do elemento quem pois, para ele, o "tradutor humano" é o objeto central da pesquisa histórica (1998, p. ix). A tradução histórica deve responder por que traduções foram produzidas em um lugar e um tempo socialmente específicos, ou seja, deve se dirigir à solução de problemas de causalidade social e somente humanos tem o tipo de responsabilidade adequada à causalidade social. Somente por meio das tradutoras e tradutores e suas redes sociais (clientes, patroas e patrões, leitoras e leitores) é possível entender por que traduções são produzidas num tempo e local histórico específico. Enfim, para se entender por que traduções ocorrem, é preciso olhar primeiramente para as pessoas envolvidas. D'hulst, por sua vez, apesar de não

\footnotetext{
${ }^{6}$ Concordo com Andrew Chesterman quando comenta que "isso não é uma surpresa, considerando seu especial interesse em tradução literária e pesquisa literária" / "[...] this is not surprising, in view of his own special interest in literary translation and research on it" (2014, p. 19).
} 
fazer nenhuma consideração especial sobre a posição do sujeito tradutor comparado aos outros loci circunstanciais, ele coloca o elemento quem como o primeiro da lista de seu hexâmetro e sempre tece algum comentário sobre como a figura do sujeito pode ser abordada mesmo quando se parte dos demais loci.

Com relação à metodologia de D'hulst de abordagem da história da tradução, o autor a desenvolve com base em oito perguntas, sendo a primeira delas "quem" (quis): "Abordar esta questão significa direcionar o foco histórico para a tradutora e o tradutor (ou, de igual modo, para a pesquisadora e o pesquisador em tradução), considerados a partir de diversos pontos de vista: contexto social ou intelectual (qualificações, gênero e perfil socioeconômico, ideológico e cultural), produção (tradutória, crítica, autoral etc.), formação e rede de relações"7 (D’HULST, 2010, p. 399). Pensando não só no/a tradutor/a mas também nos outros sujeitos que podem estabelecer algum tipo de relação com o trabalho de tradução, como o/a pesquisador/a, por exemplo, D'hulst menciona a pouca atenção que estudiosas/os da tradução têm recebido até o momento. Exceto por algumas pesquisadoras e pesquisadores de renome, é escassa a produção de memórias, biografias e trabalhos acadêmicos voltados para esses sujeitos. Ressalta, entretanto, a importância que entrevistas e produções similares podem ter futuramente para descrever o papel dessas estudiosas e estudiosos na evolução dos Estudos da Tradução (D'HULST, 2010, p. 399-400).

A segunda pergunta, "o que" (quid), direciona-se para "o que foi traduzido? E o que não foi? Em outras palavras, quais foram os critérios de seleção e os procedimentos concretos de seleção que foram aplicados aos textos a serem traduzidos?"8 (D'HULST, 2010, p. 400). Cabe também perguntar o que foi escrito sobre tradução, ou seja, quais gêneros ou tipos de reflexão foram produzidos. Os tipos mais comuns, segundo D'hulst, são prefácios, críticas, tratados, pesquisas históricas e teorias; porém, nem todos recebem a mesma atenção. Para responder a estas perguntas, faz-se necessário produzir

\footnotetext{
7"To address this question means to direct the historical focus on the translator (or, by the same token, on the translation scholar), envisaged from numerous viewpoints: intellectual and social backgrounds (training, gender, socio-economic, ideological and cultural profile), production (translational, critical, authorial etc.), group formation and network relations".

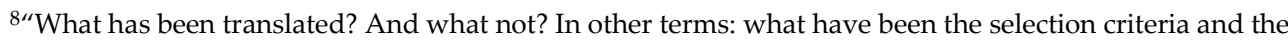
concrete selection procedures that have been applied for texts to be translated?".
} 
bibliografias de traduções existentes, bem como investigar o que poderia ter sido traduzido, mas não foi. Pensando nas bibliografias, é valido analisar quais parâmetros foram utilizados (linguístico, temporal, entre outros), bem como que tipo de suporte foram abarcados (por exemplo, seleção apenas de materiais impressos ou também de materiais publicados online) (D'HULST, 2001, p. 2526; 2010, p. 400).

A terceira pergunta é centrada no elemento "onde" (ubi). Focando especificamente nas traduções, a pergunta é "onde foram escritas, impressas, publicadas e distribuídas?"9 (D'HULST, 2001, p. 26-28; 2010, p. 400-401). O autor sugere também que as perguntas que abordem lugar sejam direcionadas aos sujeitos envolvidos no trabalho de tradução. Neste sentido, onde vivem e trabalham as/os tradutoras/es? Ou ainda, onde vivem e trabalham as/os pesquisadoras/es e as/os estudantes de tradução? (D'HULST, 2001, p. 27).

A quarta pergunta, "por quais meios" (quibus auxiliis), seria literalmente: por quais meios as/os tradutoras/es desenvolvem seu trabalho? $\mathrm{Ou}$, como formulado por D'hulst, "quais instâncias oferecem que tipo de suporte às/aos tradutoras/es?"10 (2010, p. 401). Esta pergunta, segundo o autor, está estritamente relacionada à patronagem e a outros mecanismos de controle sobre o ofício da tradução, incluindo censura, crenças, mecanismos de subsídio, preços, entre outros (D'HULST, 2001, p. 28; 2010, p. 401). Relaciona-se também às redes de relações que se estabelecem entre editoras, autoras/es e tradutoras/es, bem como às relações de poder existentes, tema muito pesquisado pelo campo que articula os Estudos da Tradução e os Estudos Pós-Coloniais.

Em quinto lugar vem "por que" (cur): por que as traduções ocorrem e por que ocorrem como ocorrem (com suas formas e funções específicas?"11 (D’HULST, 2010, p. 401). Traduções estabelecem relações específicas com textos de partida, possuindo formas e funções também específicas. Para D’hulst, essas parecem ser as perguntas de última instância da pesquisa tradutológica. Entretanto, deveriam ser descartadas por parecerem utópicas? Segundo ele, não se deve subestimar o valor heurístico de afirmações explicativas hipotéticas que

\footnotetext{
9"Where have translations been written, printed, published, distributed?".

10"Which instances offer which sort of support to translators [...]?".

11 "Why do translations occur and why do they occur the way they are (with their specific forms and functions)?".
} 
formulam respostas iniciais para perguntas, pois possuem o potencial de apontar direções possíveis para pesquisas futuras (D'HULST, 2001, p. 28-29; 2010, p. 401-402).

O sexto elemento de seu hexâmetro seria "como" (quomodo). Aqui, a indagação é: como foi o processo de criação e desenvolvimento das traduções? Como se modificaram no tempo e no espaço? D'hulst afirma que a história da comunicação tradutória e, especialmente, das normas que guiam o processo tradutório, são, de longe, as áreas mais desenvolvidas da pesquisa em história da tradução (D'HULST, 2010, p. 402).

A sétima pergunta refere-se ao elemento "quando" (quando) e é bem direta: "historicamente, quando as traduções ocorrem?"12 (D'HULST, 2001, p. 29). D'hulst comenta que esta pergunta cobre uma série de questões, como, por exemplo, o momento de origem da tradução, suas variações em certos períodos e as possíveis formas de categorização temporal. E, para ele, uma verdadeira arqueologia da tradução é ainda incipiente nesse aspecto se comparada com as conquistas alcançadas pela história dos contatos linguísticos (D'HULST, 2010, p. 402). Bibliografias de traduções poderiam ajudar a entender padrões de ocorrência em determinados períodos, caso organizadas segundo critérios de distribuição aprimorados (autoras/es, gêneros, línguas etc.) (D’HULST, 2001, p. 30).

A oitava e última pergunta, "com qual função" (cui bono), seria:"quais os efeitos da tradução, suas funções e usos na sociedade?"13 (D’HULST, 2010, p. 403). É uma pergunta central para se investigar o processo de recepção de uma tradução. A literatura comparada tem produzido uma quantidade imensa de informações sobre isso, apesar de nem sempre estarem sustentadas por uma visão clara do que este conceito significa, visto que traduções operam em redes complexas e são parte de sistemas e estruturas maiores (D'HULST, 2010, p. 403).

Essas oito perguntas fornecem uma lista de objetos de estudos, a qual não pretende ser exaustiva nem constituir um programa de pesquisa, segundo D'hulst (2001, p. 31). Sua intenção é mostrar o que pode ser estudado pela historiografia da tradução, uma disciplina ou subdisciplina que ainda precisa encontrar seu caminho nos Estudos da Tradução, de acordo com o autor. Afirma

\footnotetext{
12 "When in history does translation take place?".

13 "What are the effects of translation, their functions and uses in society?".
} 
também que há poucos exemplos de pesquisas profundas capazes de lidar com várias destas questões.

Por ser uma lista exemplificativa, D'hulst acaba por não fornecer em seus artigos $(2001,2010)$ a descrição de uma metodologia propriamente dita a ser seguida, assim como ocorreu em Pym (1998). Assim, fica em aberto o modo de condução dessa elucidação. Na pesquisa ora realizada, tentamos oferecer um possível caminho metodológico a ser seguido.

\section{A construção da metodologia: aliando a arqueologia da tradução aos recursos oferecidos por gerenciadores de referência bibliográfica}

A pesquisa que deu origem a este artigo foi conduzida em âmbito de mestrado, momento em que realizei o levantamento e a construção de um corpus não só de traduções de cantos mas também de narrativas Tupi-Guarani produzidas de 1970 a 2019, bem como uma espécie de mapeamento geral dessas traduções utilizando a fórmula metodológica e as propostas de pesquisa de D'hulst com o propósito de entender: quem são as tradutoras e tradutores desses cantos, focando nos aspectos de gênero e etnia (especificamente se indígena ou não indígena), bem como em seu ofício ou profissão (na maioria dos casos, a tradução não constitui seu primeiro ofício); em que tipo de publicação as traduções estão inseridas (livro, tese, artigo etc.); a área do conhecimento de onde partiram as iniciativas; qual a natureza das instituições que auxiliaram o processo de criação e publicação dos cantos (universidade, editora tradicional, editora independente etc.); quando foram publicadas; quais as principais características dessas traduções (tradução original ou retradução, direta ou indireta, assistida ou não por outro/a tradutor/a ou intérprete, comentada ou não comentada, apresentação em formato bilíngue ou monolíngue) ${ }^{14}$.

Foi uma investigação inédita, feita no âmbito dos Estudos da Tradução no Brasil, e que resultou em uma compilação de 233 cantos traduzidos. Acredito que representem apenas um indício de algo muito maior ainda a ser descoberto,

\footnotetext{
${ }^{14}$ Para mais informações sobre o corpus de traduções construído, a metodologia desenvolvida e os resultados do mapeamento feito, consultar: BARBOSA, Helena Lúcia Silveira. A tradução de cantos e narrativas Tupi-Guarani (1970 - 2019): um corpus historiográfico. Dissertação (Mestrado em Estudos da Tradução) - Faculdade de Filosofia, Letras e Ciências Humanas, Universidade de São Paulo, 2019.
} 
visto que resultaram de um esforço individual de pesquisa de aproximadamente dois anos e meio.

Obedeceu a três critérios de recorte. O primeiro critério é ordem linguística: trata-se do levantamento e mapeamento de traduções para o português de cantos exclusivamente Tupi-Guarani, que é a maior família linguística do tronco Tupi e, segundo o linguista Aryon Dall'igna Rodrigues (2002, p. 32), destaca-se entre outras famílias linguísticas do Brasil e da América do Sul pela extensão territorial sobre a qual suas línguas estão distribuídas. Optamos por trabalhar com a família linguística Tupi-Guarani em razão de sua ampla distribuição geográfica e por sua importância histórica no processo de formação do Brasil. No século XVI, essas línguas eram faladas em praticamente toda a costa brasileira e na bacia do rio Paraná, sendo que ainda hoje encontramse registros de falantes em todas as regiões do país. Interessante notar que, apesar dessa grande dispersão geográfica, essas línguas revelam pouca diferenciação entre si.

Nos dias atuais, entre as cerca de 150 línguas indígenas faladas por povos indígenas no Brasil (EQUIPE DE EDIÇÃO DA ENCICLOPÉDIA POVOS INDÍGENAS NO BRASIL, [s.d.]), 21 fazem parte da família linguística TupiGuarani. O quadro a seguir apresenta as línguas e dialetos que integram essa família linguística, a localização dos respectivos povos falantes e o número de traduções coletadas; as línguas e dialetos nos quais foi possível encontrar cantos traduzidos estão em destaque ${ }^{15}$.

\footnotetext{
${ }^{15} \mathrm{As}$ línguas e dialetos apresentados têm, tanto hoje quanto no período do levantamento, diferentes situações de vitalidade linguística, número de falantes e dispersão geográfica. Algumas estão praticamente extintas, como o apiaká, que conta apenas com um par de falantes, já em idade muito avançada. Outras, como o guarani e suas variantes dialetais, têm grande vitalidade linguística e são faladas em um vasto território, por diferentes comunidades.
} 
Tabela 1 - Línguas da família Tupi-Guarani no Brasil e total de traduções encontradas

\begin{tabular}{|c|c|c|c|}
\hline Língua & Dialeto & Estado & $\begin{array}{l}\text { Traduções de } \\
\text { cantos }\end{array}$ \\
\hline \multirow{3}{*}{ Akwáwa } & Aikewara (ou Suruí do Tocantins) & PA & 0 \\
\hline & Asuriní do Tocantis (ou Asuriní do Trocará) & PA & 0 \\
\hline & Parakanã (ou Awaeté) & PA & 0 \\
\hline \multicolumn{2}{|l|}{ Amanayé } & PA & 0 \\
\hline \multicolumn{2}{|l|}{ Anambé } & PA & 0 \\
\hline \multicolumn{2}{|l|}{ Apiaká } & MT, PA & 0 \\
\hline \multicolumn{2}{|l|}{ Araweté } & PA & 27 \\
\hline \multicolumn{2}{|c|}{ Asuriní do Xingu (ou Asuriní do Pacará ou do Koatinemo) } & PA & 0 \\
\hline \multicolumn{2}{|c|}{ Avá-Canoeiro } & TO, GO & 0 \\
\hline \multicolumn{2}{|l|}{ Guajá (Awá) } & MA & 3 \\
\hline \multirow{3}{*}{ Guarani } & Kaiowá & MS & 66 \\
\hline & Mbya & ES, PA, PR, RJ, RS, SC, SP, TO & 18 \\
\hline & Ñandeva & MS, PR, RS, SC, SP & 6 \\
\hline \multicolumn{2}{|l|}{ Ka'apor } & MA & 0 \\
\hline \multirow{7}{*}{ Kagwahiva } & Amondawa & $\mathrm{RO}$ & 0 \\
\hline & Jiahui (Diahói) & $\mathrm{AM}$ & 0 \\
\hline & Juma & $\mathrm{AM}$ & 0 \\
\hline & Karipuna de Rondônia (Ahé) & $\mathrm{RO}$ & 0 \\
\hline & Parintintim & $\mathrm{AM}$ & 0 \\
\hline & Tenharim & $\mathrm{AM}$ & 0 \\
\hline & Uru-eu-wau-wau & $\mathrm{RO}$ & 0 \\
\hline \multicolumn{2}{|c|}{ Kaiabi (Kawaiwete) } & MT & 32 \\
\hline \multicolumn{2}{|l|}{ Kamaiurá } & MT & 65 \\
\hline \multicolumn{2}{|c|}{ Kambeba (Omaguá) } & $\mathrm{AM}$ & 2 \\
\hline \multicolumn{2}{|l|}{ Kokama } & $\mathrm{AM}$ & 0 \\
\hline \multicolumn{2}{|l|}{ Nheengatu } & $\mathrm{AM}$ & 11 \\
\hline \multicolumn{2}{|l|}{$\begin{array}{l}\text { Tapirapé } \\
\text { (Apyãwa) }\end{array}$} & MT, TO & 3 \\
\hline \multirow[t]{2}{*}{ Tenetehara } & Guajajara & MA & 0 \\
\hline & Tembé (Tenetehara) & MA, PA & 0 \\
\hline \multicolumn{2}{|l|}{ Wajãpi } & $\mathrm{AP}, \mathrm{PA}$ & 0 \\
\hline
\end{tabular}




\begin{tabular}{lll} 
Xetá & PR & 0 \\
\hline Zo'é & PA & 0 \\
\hline Total de tradução de cantos Tupi-Guarani & & $\mathbf{2 3 3}$ \\
\hline
\end{tabular}

Apesar de ter sido possível construir um corpus bem amplo em número de línguas Tupi-Guarani, não conseguimos encontrar traduções em onze destas línguas e dialetos, seja por não terem mais falantes nativos, por não terem registros textuais publicados de suas formas de expressão oral ou porque, simplesmente, não encontramos publicações que contivessem traduções que obedecessem aos parâmetros estabelecidos pela pesquisa.

Em razão da notável historicidade dessa família linguística, contando com uma tradição escrita que remonta a cerca de 400 anos, estabelecemos um segundo critério de recorte com base no lapso temporal. O levantamento restringiu-se aos anos de 1970 até 2019, compreendo um período de 50 anos. Conforme dito anteriormente, a partir da década de 1970, a documentação das tradições orais começa a ser feita de modo mais sistemático e os materiais desenvolvidos passam a ser analisados com uma compreensão mais sofisticada das línguas e de suas configurações rituais e poéticas, revelando uma série de características das artes verbais até então incompreensíveis (CESARINO, 2013). Muitas das traduções feitas neste período, assim, possuem informações complementares, como comentários sobre seu processo de execução e informações sobre o original que serviu de fonte para a tradução, materiais extratextuais de suma importância para a condução do mapeamento como o pretendido pela pesquisa.

O terceiro critério relaciona-se ao que foi considerado tradução ou não. O recorte baseou-se na existência de textos bilíngues na publicação analisada, referentes ao texto original e à tradução. Já no caso de publicações apenas com textos em português, considerou-se tradução quando houve menção do próprio autor da publicação de que o texto se tratava de uma tradução.

Quanto às etapas da pesquisa, a primeira focou no levantamento, conduzido por meio de pesquisa bibliográfica para a construção do corpus, enquanto a segunda foi direcionada ao mapeamento das traduções e dividiu-se em dois momentos: organização e sistematização dos dados do corpus em um 
programa computacional de gerenciamento de referências bibliográficas; e análise dos dados.

Durante a primeira etapa, a pesquisa bibliográfica foi feita por um processo de verdadeira escavação documental. Por ser um trabalho inédito, não foi possível basear-nos em catálogos ou corpus precedentes que pudessem servir de ponto de partida. O processo de levantamento de cantos traduzidos, assim, partiu praticamente do zero, salvo algumas poucas referências bibliográficas que já havíamos coletado por ocasião de estudos anteriores. Baseou-se em bases de dados digitais e físicos, variando de catálogos de teses a repositórios institucionais; as principais bases utilizadas foram: o Portal do Sistema Integrado de Bibliotecas da Universidade de São Paulo - SIBiUS; a Biblioteca Digital Curt Nimuendajú; e os repositórios institucionais do Summer Linguistics Institute (SIL) ${ }^{16}$ e do Instituto Socioambiental (ISA). Cada uma dessas bases revelou tanto vantagens quanto limitações em matéria de mecanismos de busca e acervo. Após a consulta das publicações e seleção das traduções, o corpus foi construído.

Demos início então à segunda etapa. As bibliografias encontradas foram organizadas no Zotero, um gerenciador de referências bibliográficas em código aberto (software livre) e de fácil manuseio. Esse gerenciador mostrou-se extremamente útil para a pesquisa realizada, pois, além de otimizar substancialmente o processo de mapeamento bibliográfico e permitir analisar muito mais dados do que manualmente, possibilitou organizar as entradas bibliográficas em coleções, correspondentes às 21 línguas Tupi-Guarani, e sistematizá-las por meio de etiquetas, multiplicando as possibilidades de cruzamentos de variáveis e, consequentemente, o alcance quantitativo da pesquisa. Devemos mencionar ainda a possibilidade de enriquecimento permanente da base de dados e a facilidade que proporciona para a publicação dos dados, tanto de forma digital quanto impressa.

Foi no processo de etiquetagem onde os loci circunstanciais sugeridos por Lieven D'hulst para o estudo da história e da historiografia da tradução foram aplicados. Eles serviram de base para a concepção de classes de análise das traduções, sendo que cada classe corresponde literalmente a um locus

\footnotetext{
16 Atualmente, Sociedade Internacional de Linguística.
} 
(quem, o que, quando etc.). Cada classe, por sua vez, foi dividida em categorias, designadas por meio de etiquetas; as sugestões de pesquisa fornecidas por D'hulst em cada locus foram aplicadas na pesquisa para o desenvolvimento de categorias específicas ao corpus com que trabalhamos. As etiquetas criadas, em negrito na tabela, podem ser resumidas da seguinte forma:

\begin{tabular}{|c|c|}
\hline $\begin{array}{l}\text { O que } \\
\text { (quid) }\end{array}$ & $\begin{array}{l}\text { Tipo de publicação: livro; tese (englobando tese, } \\
\text { dissertação e monografia); artigo de periódico; } \\
\text { material didático; outro (relatório institucional, } \\
\text { produto de consultoria etc.). }\end{array}$ \\
\hline \multirow{7}{*}{$\begin{array}{l}\text { Quem } \\
\text { (quis) }\end{array}$} & $\begin{array}{l}\text { Autor da publicação: autor; autor-tradutor; } \\
\text { organizador; organizador-assistente. }\end{array}$ \\
\hline & Área do/a tradutor/a: [ofício do tradutor]. \\
\hline & $\begin{array}{l}\text { Em diversos casos mapeados, as traduções foram } \\
\text { realizadas por antropólogos, linguistas, } \\
\text { etnomusicólogos, educadores, entre outros. Apenas } \\
\text { em alguns casos pontuais foram realizadas por } \\
\text { tradutoras/es que reconhecem a tradução como seu } \\
\text { primeiro ofício ou profissão. Por isso, as categorias } \\
\text { dessa subclasse variaram de acordo com o ofício ou } \\
\text { profissão dos sujeitos criadores das traduções. }\end{array}$ \\
\hline & Gênero do/a tradutor/a: mulher; homem. \\
\hline & $\begin{array}{l}\text { Não inclui a categoria "não-binário" (a qual abarca a } \\
\text { multiplicidade de gênero, a ausência de gênero e a } \\
\text { parcialidade de gênero, entre outros), pois, em } \\
\text { nenhum dos casos investigados, foi possível } \\
\text { identificar sujeitos que pertencessem a essa } \\
\text { categoria. }\end{array}$ \\
\hline & Etnia do/a tradutor/a: indígena; não indígena. \\
\hline & $\begin{array}{l}\text { O objetivo aqui não foi verificar a distribuição de } \\
\text { traduções entre diferentes etnias existentes, mas sim } \\
\text { entender a presença de indígenas no universo das } \\
\text { tradutoras e tradutores de cantos Tupi-Guarani no } \\
\text { Brasil. }\end{array}$ \\
\hline & [área do conhecimento]. \\
\hline $\begin{array}{c}\text { Onde } \\
(u b i)\end{array}$ & $\begin{array}{l}\text { O foco não recaiu sobre a distribuição geográfica das } \\
\text { publicações (ou, como propôs Lieven D'hulst, onde } \\
\text { foram escritas, impressas, publicadas e distribuídas), } \\
\text { mas sim sobre as áreas do conhecimento de onde } \\
\text { partiram as traduções. }\end{array}$ \\
\hline $\begin{array}{l}\text { quais meios } \\
\text { uns auxiliis) }\end{array}$ & $\begin{array}{l}\text { Editora; universidade; organização indígena; } \\
\text { Museu do Índio; independente. }\end{array}$ \\
\hline
\end{tabular}


Esta classe se refere especificamente às instituições que auxiliaram a criação e publicação das obras nas quais as traduções estão inseridas.

[ano de publicação]; [década de publicação].

Quando

(quando)

A divisão entre ano e década foi estabelecida para que fosse possível pensar os períodos históricos a partir de dois referenciais temporais distintos.

Quanto ao texto de partida: tradução original; retradução.

Quanto à língua de partida: direta; indireta.

Quanto à assistência

Tipo de tradução recebida para a execução

Como (quomodo) da tradução: autônoma; assistida.

Quanto à existência de comentários: comentada; não comentada.

Apresentação do texto: monolíngue; bilíngue; monolíngue e bilíngue (no caso de publicações que contém textos nos dois formatos).

Cabe observar que não aplicamos os loci circunstanciais cur (por qual motivo as traduções ocorrem) e cui bono (quais os efeitos da tradução, suas funções e usos na sociedade) à pesquisa realizada. Pensando a partir da divisão feita por Pym (1998) da história da tradução, apesar desses dois elementos terem sido inseridos pelo autor na área arqueológica, enquadram-se mais propriamente na "explicação", a terceira área deste campo de estudos, exatamente aquela que tenta responder as razões de ocorrência dos artefatos arqueológicos e as relações de causalidade que surgem disso. Em nosso entendimento, abordar essas perguntas na pesquisa proposta extrapolaria seus objetivos arqueológicos. Merecem ser abordadas em outro momento, em um estudo específico direcionado à preencher as lacunas existentes na área da "explicação".

Com relação ao cruzamento das etiquetas no gerenciador bibliográfico, mostrou-se extremamente interessante e eficaz em termos metodológicos, pois forneceu dados quantitativos de vários tipos que auxiliaram a montar um mapeamento de larga escala dos cantos Tupi-Guarani traduzidos para o português nos últimos 50 anos, envolvendo e combinando diferentes loci 
circunstanciais. Por exemplo, ao cruzar a etiqueta "década da publicação" com "mulher", foi possível verificar a presença de tradutoras mulheres por década e fazer um comparativo; inserindo a etiqueta "indígena" nesse cruzamento, pudemos perceber quantas dessas tradutoras eram indígenas e quantas não. Enfim, as possibilidades de cruzamentos e análises são vastas, conforme pode ser verificado no mapeamento apresentado a seguir.

Mapeamento: o cenário da tradução de cantos Tupi-Guarani de 1970 até os dias de hoje

1. Traduções e retraduções

\section{Gráfico 1 - Distribuição de traduções e retraduções por década}

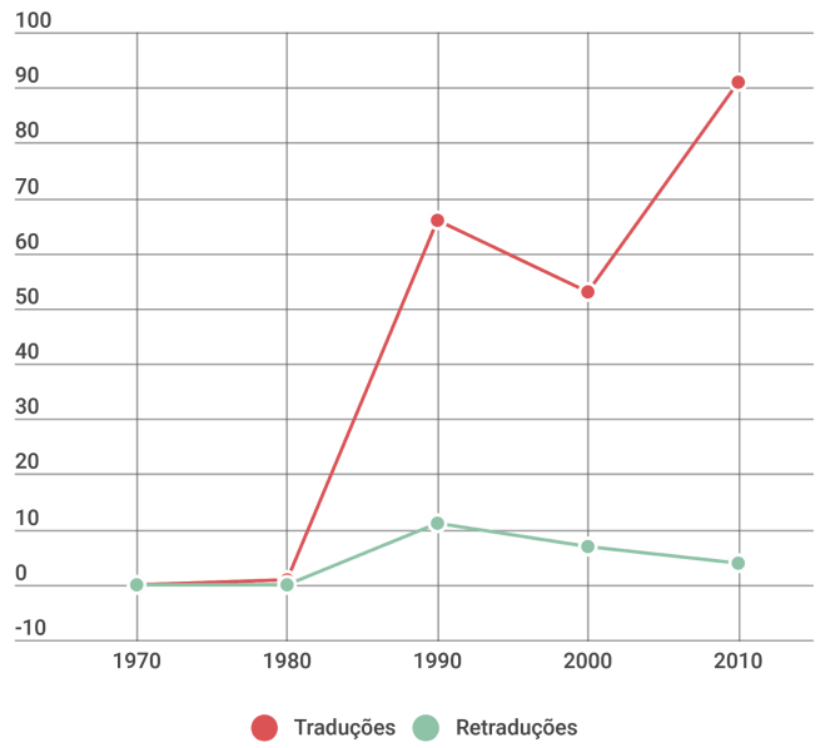

O material surpreende pela diversidade das traduções encontradas em termos de originalidade, formato de apresentação dos textos e notas utilizadas pelas/os tradutoras/es e editoras/es, as quais enriquecem em muito a 
compreensão linguística e do pensamento nativo. Do total de 233 cantos, 211 foram traduzidos originalmente, enquanto 22 enquadram-se como retraduções ${ }^{17}$. Com relação às retraduções, correspondem a cantos que, podemos dizer, já possuem certa notoriedade entre os pesquisadores e interessados pelo tema, como o Ayvu Rapyta, o gênesis guarani, que mereceu dez retraduções de alguns de seus capítulos, e o Canto da Castanheira, canto araweté, que foi retraduzido duas vezes.

A partir da observação da distribuição quantitativa dessas traduções ao longo das cinco décadas estudadas, verificou-se que a atividade da tradução prevaleceu sobre a atividade da retradução (e que a tendência, aparentemente, é continuar dessa forma, pelo menos a curto prazo).

Enquanto na década de 1970 não houve nenhum registro de traduções e na década de 1980 há uma única tradução (o Canto da Castanheira, traduzido por Viveiros de Castro), a partir da década de 1990 nota-se um crescimento substancial de traduções (66), sendo que A Festa da Jaguatirica (1990) foi responsável por 65 delas. O número de traduções na década seguinte decai um pouco (53), mas volta a crescer na década de 2010 (91). Como se vê, a década de 1990 é um momento de transformação positiva para o campo da tradução de cantos Tupi-Guarani no Brasil.

As retraduções, por sua vez, ocorrem em bem menor proporção. Surgem apenas na década de 1990 (11 retraduções) e, nas décadas seguintes, continuam presentes, apesar de ainda pouco representativas se comparadas às traduções (sete retraduções na década de 2000 e quatro na década de 2010). A retradução, assim, permaneceu como uma atividade minoritária no campo da tradução de cantos Tupi-Guarani no período analisado.

Desse modo, vemos a preferência de tradutoras e tradutores em realizar traduções originais a partir de materiais coletados em primeira mão. Isso é compreensível ao observamos como as fontes de tradições orais ameríndias

\footnotetext{
${ }^{17}$ Como retradução, assumimos os quatro primeiros sentidos apresentados por Álvaro Faleiros em seu artigo A noção de retradução nos estudos da tradução: um percurso teórico (2014, p. 38-39), no qual retoma definições propostas por Ladmiral (2012), Chevrel (2010) e Gambier (2012). Retradução como nova tradução de um mesmo texto de partida; revisão de uma tradução já realizada; retrotradução (retraduzir, na mesma língua do "original", uma tradução desse "original"; e tradução de uma tradução (uma tradução intermediária é tomada como texto de partida). Não considerei apenas o quinto sentido, segundo o qual retradução pode ser toda e qualquer tradução, na medida em que é possível que toda tradução seja por si só uma retradução, pois conflitaria com a primeira categoria proposta.
} 
foram pouco exploradas como objetos de tradução até hoje, principalmente os cantos, o que se justifica pelas dificuldades inerentes à compreensão e tradução deste gênero verbal. Os cantos, por possuírem uma "expressão formular"18, são traduzidos comumente no formato de poema, com versos e estrofes. Também, envolvem aspectos adicionais que dificultam ainda mais a tradução, como rima, ritmo e vocalização. Atestando este ponto, cito mais uma vez o comentário do antropólogo Uirá Garcia sobre sua dificuldade de traduzir os cantos Guajá: “Traduzir esses cantos é uma tarefa ainda por fazer, pois diferente das narrativas, o canto parece falar em um outro idioma, muitas vezes com gemidos e vocalizes que ocultavam totalmente as palavras" (2010, p. 401). Ademais, poucos são os textos que ganharam divulgação e circularam suficientemente a ponto de se tornarem objeto de interesse para uma possível retradução, como é o caso do Ayvu Rapyta guarani e do Canto da Castanheira araweté, por exemplo.

\section{Traduções comentadas e traduções não comentadas}

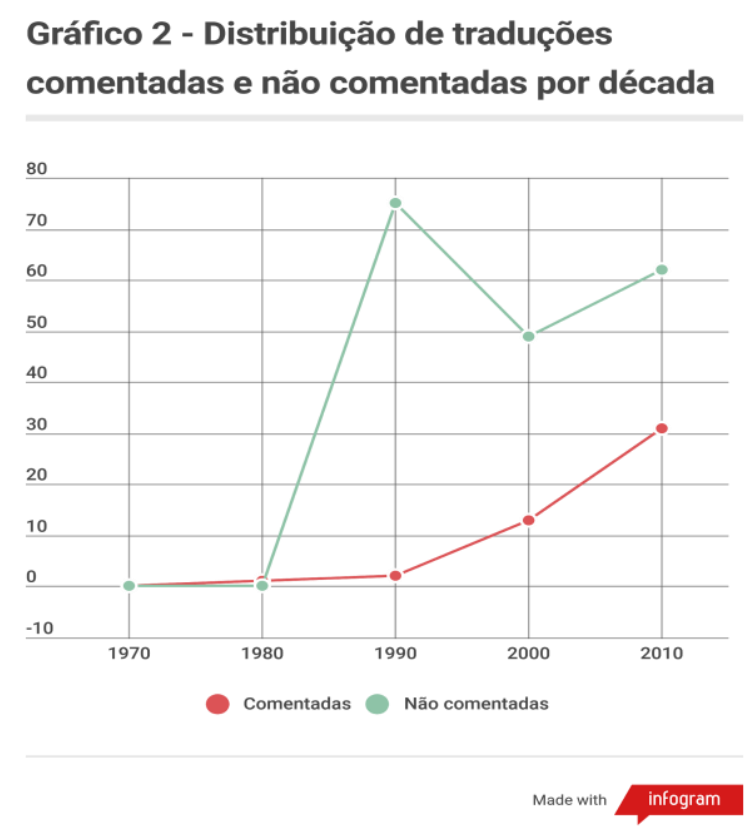

\footnotetext{
${ }^{18}$ Este é um conceito originado nas análises de Perry e Lord (Lord 1971) sobre poesia homérica, o qual corresponde ao grupo de palavras que segue as mesmas condições métricas para expressar uma ideia central, seguindo o padrão de fórmulas. Os trabalhos desses autores geraram uma série de debates Finnegan (1977), Foley (1988) e Zumthor (2003; 2010) - e a noção de expressão formular tem sido atualmente aplicada para a análise de cantos ameríndios, como por Cesarino para pensar os cantos marubo $(2011 ; 2013)$ e por Heurich para pensar os cantos araweté (2015).
} 
O mapeamento revelou também que a produção de traduções não comentadas foi consideravelmente superior a de traduções comentadas (186 e 47, respectivamente).

A partir do seu aparecimento na década de 1990, as traduções não comentadas sobrepõem-se às comentadas em todas as décadas (na década de 1990, 75 não comentadas em contraposição a apenas duas comentadas; na década de 2000, 49 em contraposição a 13; e na década de 2010, 62 em contraposição a 31). Entretanto, apesar da clara preferência de tradutoras/es em produzir traduções não comentadas de cantos Tupi-Guarani, observa-se um aumento gradual da publicação de textos comentados, o que é um ponto extremamente positivo, dado às especificidades atinentes aos cantos nativos e à relevância que comentários tem para sua melhor compreensão. $\mathrm{O}$ universo poético ameríndio, muitas vezes, necessita de elucidações que extrapolam o conteúdo linguístico, posto que perpassam questões de ordem metafísica e ontológica. As notas e comentários, assim, são uma forma de aproximar o leitor não familiarizado com este tipo de pensamento e repertório criativo, bem como permitem-no acessar o conteúdo de forma mais profunda e diminuir a estranheza causada por algumas dessas textualidades. Clastres (1990), por exemplo, ao traduzir cantos sagrados guarani, afirma que suas notas servem essencialmente para auxiliar o leitor que não tem familiaridade com o pensamento guarani. A compreensão da linguagem, assim, demanda a compreensão da visão de mundo guarani; a primeira resulta diretamente da segunda.

\section{Distribuição das traduções por tipo de publicação}




\section{Gráfico 3 - Distribuição dos tipos de publicação por década}

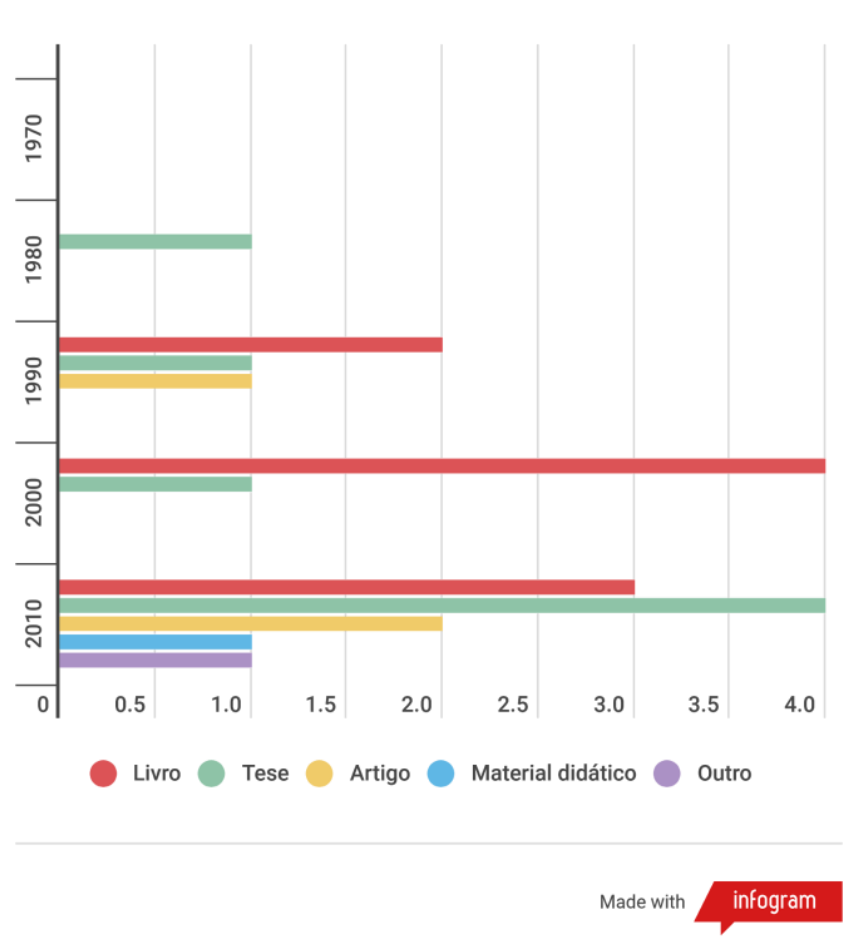

As traduções encontradas estão distribuídas em 21 publicações, divididas em nove livros, sete teses e dissertações, três artigos de periódicos, um material didático e um documento, produto de um projeto de documentação linguística. Como se pode ver no gráfico apresentado, com o passar das décadas, houve um aumento gradual tanto da quantidade geral de publicações como da variedade de tipos de publicação, sendo importante ressaltar que a última década registrou publicações de todos os tipos abordados pelo levantamento. Neste sentido, observa-se uma tendência de crescimento do número de publicações de traduções, que é extremamente favorável para o campo da tradução das artes verbais Tupi-Guarani, pois revela que tem havido um maior interesse sobre este tipo de texto, interesse que só tem aumentado com o passar do tempo, não apenas do ponto de vista da produção, mas também do consumo - lembremos da Lei 11.645/2008, que estabeleceu a obrigatoriedade das escolas públicas e privadas brasileiras de trabalharem com a temática indígena em seu currículo, contribuindo para impulsionar esses dois aspectos. Segundo informa o escritor Daniel Munduruku, essa exigência educacional "fez com que houvesse um interesse maior por parte das editoras na parte da produção e, é 
claro, isso demandou, da parte do governo, a aquisição de livros sobre essa temática indígena para enviar às escolas". Segundo ele, o crescimento foi tão grande que os próprios indígenas que escrevem "não conseguem dar conta, tamanha a demanda que está hoje nos solicitando" (GANDRA, 2013). Diversas editoras aproveitaram tal demanda e um nicho pouco explorado para apostar nas publicações, como a Global Editora, que, desde os anos 1990, investe na temática indígena (CÂMARA, 2012). Essa editora foi responsável pelo lançamento de títulos importantes da literatura indígena, como $A$ sabedoria das águas e A primeira estrela que vejo é a estrela do meu desejo (2007), de Daniel Munduruku, e Metade cara, metade máscara (2004), de Eliane Potiguara. Podemos mencionar ainda as novas possibilidades oferecidas pelo mercado editorial online, que abre espaço de atuação para editoras e livrarias que trabalham especificamente com este tipo de produção textual, como a Livraria Maracá, uma livraria online especializada em literatura indígena produzida no Brasil. Aliás, livrarias como a Maracá favorecem grandemente o crescimento do consumo desse tipo de texto, pois reúnem em um mesmo ambiente virtual obras de diversas/os escritoras/es indígenas de todo o Brasil, como Eliane Potiguara, Daniel Munduruku, Graça Graúna, Kaká Werá Jecupé, Yaquarê Yamã, Olívio Jekupé, entre tantas/os outra/os, que encontram em pequenas e médias editoras espaço para publicação.

\section{Publicações contendo traduções apresentadas em formato bilíngue e monolíngue}

Gráfico 4 - Distribuição de publicações contendo textos em formato monolíngue e bilíngue por década

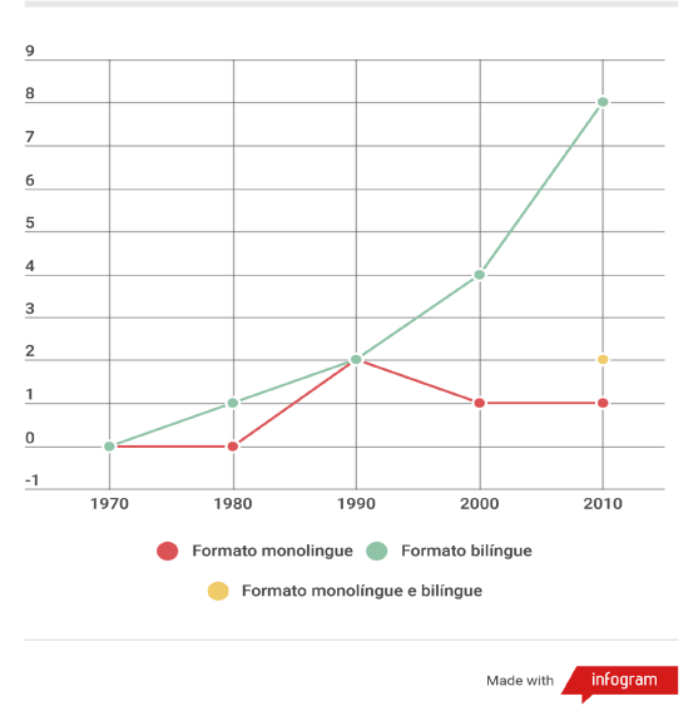


Pode-se observar no gráfico apresentado uma preferência ao longo das décadas pela publicação de cantos traduzidos em formato bilíngue, ou seja, contendo tanto as traduções como os textos de partida em línguas Tupi-Guarani. Enquanto as publicações com cantos bilíngues demonstraram um crescimento ao longo das décadas analisadas (uma publicação na década de 1980, duas na década de 1990, quatro na década de 2000 e oito na década de 2010), as publicações contendo somente os cantos traduzidos para o português corresponderam a quase um terço daquelas (duas na década de 1990, uma na década de 2000 e uma na última década). Na década de 2010, aliás, surgiram as primeiras publicações que apresentaram cantos nos dois formatos (duas no total).

Essa possível preferência pela confecção de publicações em formato bilíngue pode ser um indicativo de que tem havido um esforço de divulgação não só dos cantos mas também das línguas Tupi-Guarani, as quais têm ganhado visibilidade e interesse não só por parte do leitorado especializado da academia, como antropólogos e linguistas, mas também do leitor comum que se interessa pelo tema, sejam adultos ou jovens e crianças. Aproximar o/a leitor/a a essas línguas e suas especificidades estilísticas e, em última instância, às culturas e povos a elas relacionadas pode ser extremamente positivo para o desenvolvimento de um olhar menos exotizante sobre as experiências poéticas indígenas.

5. Instituições que auxiliaram no processo de produção e publicação das traduções 


\section{Gráfico 5 - Distribuição das publicações de acordo com as instituições responsáveis por sua publicação por década}

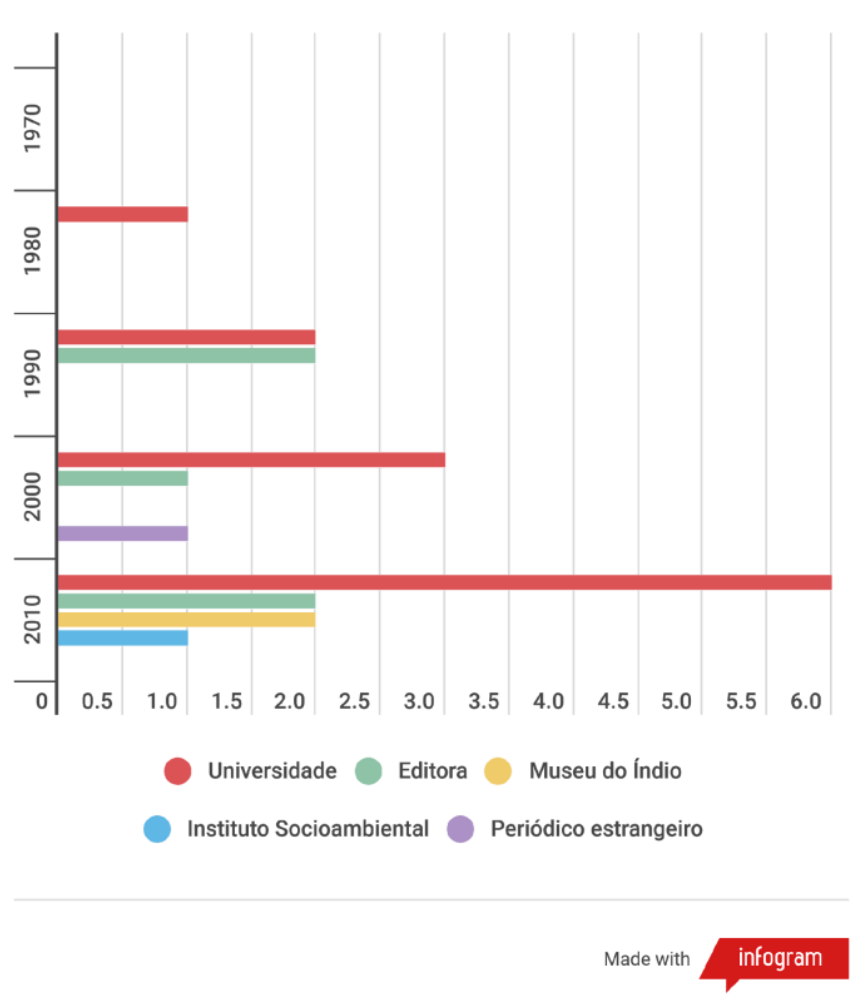

Instituições de diversas localidades foram responsáveis pela produção, publicação e divulgação de traduções de cantos Tupi-Guarani. As universidades revelaram-se como os grandes polos de publicação, sendo que não podemos deixar de mencionar a importância dos centros de documentação linguística ligados às tradições orais indígenas nesse processo. Outras instituições, como editoras tradicionais e organizações que desenvolvem trabalhos junto a povos indígenas, como o Museu do Índio e o Instituto Socioambiental, também passaram a configurar como agentes nesse processo, principalmente a partir de 2010.

Com relação às áreas do conhecimento que mais produziram pesquisas sobre cantos Tupi-Guarani nos últimos 50 anos, a antropologia predominou (11 
publicações), seguida da literatura (5 publicações), que vem traçando um caminho cada vez mais consistente nesse sentido. A linguística apresentou três publicações e a educação, por sua vez, duas publicações. Cabe ressaltar, porém, que tais áreas ainda trabalham de forma isolada. Torna-se cada vez mais clara a necessidade de se criar um campo de pesquisas ativamente interdisciplinar tendo em vista a própria natureza múltipla dos cantos ameríndios, em que diferentes áreas e pesquisadores possam contribuir com suas expertises específicas e aliar esforços em busca de soluções para problemas comuns. Os conhecimentos de um antropólogo sobre um determinado povo indígena, por exemplo, devem somar-se às expertises de um linguista e de um tradutor para que se produza uma boa tradução (boa no sentido de contemplar as especificidades apresentadas pelas formas de expressão verbal ameríndia e seus repertórios criativos). No caso de um canto ritual, por exemplo, a presença de um etnomusicólogo é indispensável. E, se este texto tiver como destino final o uso em sala de aula, um educador tem muito a contribuir com esta tarefa. Como afirma Antônio Risério, "não só os poetas precisam abrir os olhos e o coração para a poesia indígena (e africana), como os etnógrafos precisam nos mostrar mais sistematicamente a colheita poética de suas expedições" (1992, p. 2). Essa aliança de esforços certamente poderá favorecer o desenvolvimento de um campo sólido de pesquisas direcionado aos cantos indígenas.

6. Tradutoras/es e intérpretes indígenas e não indígenas 


\section{Gráfico 6 - Distribuição de tradutoras/es de acordo com gênero e etnia por década}

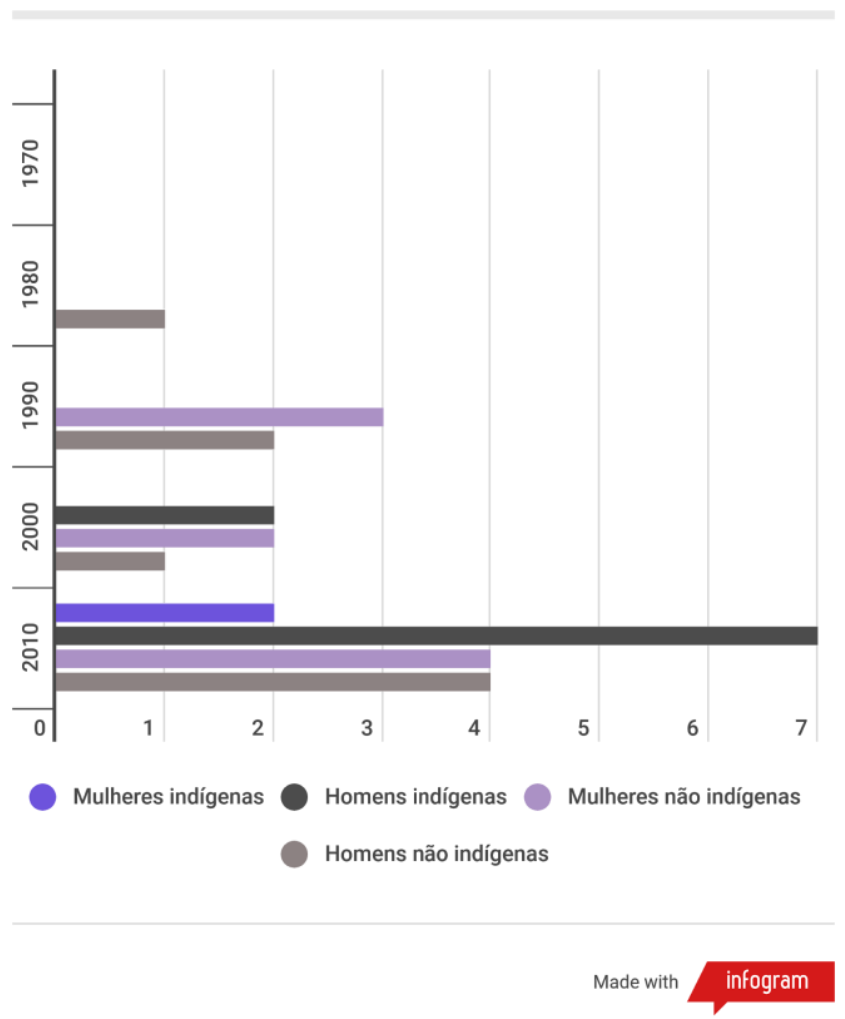

Quanto aos sujeitos tradutores, o levantamento mostrou que mulheres e homens não indígenas ocuparam o campo da tradução de cantos Tupi-Guarani em proporção equivalente ao longo das últimas cinco décadas, porém com uma pequena predominância das mulheres (nove tradutoras em comparação a oito tradutores nas publicações analisadas). Quanto às tradutoras e tradutores indígenas, aparecem somente na quarta e quinta décadas estudadas, sendo que os homens, dessa vez, ocorreram em bem maior número (nove tradutores e duas tradutoras indígenas). Como é possível visualizar no gráfico, os tradutores indígenas despontaram na última década na frente dos outros três grupos, assumindo uma posição importante de protagonismo nesse cenário. É importante ressaltar, entretanto, que as mulheres, indígenas e não indígenas, estiveram presentes em número considerável e seguem aumentando sua participação, o que é muito positivo, pois indica que, futuramente, a pesquisa 
em tradução de cantos Tupi-Guarani pode vir a ter importantes contribuições femininas (e feministas) em termos de prática tradutória e de teorização.

Deve-se ressaltar o fato de que mais de 33 tradutoras e tradutores indígenas - além desses 33, uma pesquisa específica (PAULA, 2012) afirma que as/os tradutoras/es foram professoras/es indígenas tapirapé, mas não diz quantos - não tiveram o gênero identificado em certas obras publicadas da década de 1990 à década de 2010. Apesar de não ter sido possível determinar a distribuição entre mulheres e homens nesses casos, é um número por si só significativo, pois revela a presença abundante dos tradutoras/es indígenas nas últimas três décadas no trabalho de tradução de cantos Tupi-Guarani. Sendo assim, o que se conclui é que o número de tradutoras/es indígenas foi bem superior ao de tradutoras/es não indígenas nas cinco últimas décadas.

Os intérpretes indígenas (homens especificamente) também estiveram presentes e figuraram no cenário dos cantos traduzidos nas últimas três décadas. Entretanto, o número ficou bem abaixo do que era esperado inicialmente, visto que a pesquisa de campo com povos indígenas normalmente demanda o uso da interpretação realizada por indígenas e muitas das traduções partem de cantos e narrativas orais coletados. Em duas publicações (MONTARDO, 2002; GARCIA, 2010), por exemplo, há a menção de que as/os tradutoras/es obtiveram a ajuda de intérpretes indígenas para a realização das traduções, sem especificação da quantidade. Neste sentido, acredita-se que, muito possivelmente, intérpretes estiveram presentes em número bem maior do o verificado. Esta é uma hipótese que certamente merece ser investigada. Ao que parece, as/os intérpretes indígenas possuem menos visibilidade do que as/os tradutoras/es indígenas, com exceção de alguns casos históricos de destaque. Um estudo sobre as/os intérpretes indígenas que trabalham ou trabalharam como assistentes nos trabalhos de campo de coleta de cantos seria fundamental para se investigar essa questão.

\section{O corpus de cantos traduzidos}

Após esta breve apresentação do mapeamento realizado e dos resultados obtidos, adentraremos especificamente na descrição cronológica do corpus de 
traduções catalogadas para que seja possível compreender o teor do material coletado, sua extensão e diversidade.

A década de 1970 experiencia um afloramento da prática da tradução de artes verbais, principalmente com a emergência do movimento etnopoético no contexto americanista por meio dos seus principais expoentes: os norteamericanos Dell Hymes, Dennis Tedlock e Jerome Rothenberg. No Brasil, este movimento chega com força e influência, resultando no surgimento de importantes trabalhos sobre as artes de expressão verbal de diversos povos indígenas. No âmbito das línguas Tupi-Guarani, há a publicação de traduções de narrativas Tupi-Guarani (especificamente, três publicações sobre mitologia kamaiurá); os cantos, entretanto, só passarão a ser objeto de tradução a partir da década seguinte.

Na década de 1980, ocorre a publicação de uma das pesquisas de maior importância já realizada sobre os Araweté, a qual inaugura o cenário da tradução para o português de cantos Tupi-Guarani. Em Araweté: os deuses canibais (1984) ${ }^{19}$, o antropólogo Eduardo Batalha Viveiros de Castro apresenta uma etnografia sobre os Araweté, focada na descrição e na interpretação de sua cosmologia. Os Araweté são um povo de caçadores e agricultores que tiveram uma longa história de guerras, fugas e mortes, bem como experimentaram uma catástrofe demográfica em razão do contato com os brancos (VIVEIROS DE CASTRO, [s.d.]). Apesar de possuírem uma cultura material relativamente simples quando comparados a outros povos Tupi-Guarani, apresentam, em contrapartida, um discurso cosmológico complexo. Nas palavras de Viveiros de Castro, "o imaginário Araweté prolifera na palavra e no canto" (VIVEIROS DE CASTRO, 1986, p. 23).

Com vistas a entender os traços centrais dos cantos xamanísticos desse povo, Viveiros de Castro traduz "O Canto da Castanheira", coletado e traduzido por ele durante sua pesquisa de campo entre os Araweté. O canto é apresentado em formato bilíngue. Segundo o próprio autor, produz uma tradução livre do canto (VIVEIROS DE CASTRO, 1986, p. 550 - 564) e a intercala com notas

\footnotetext{
${ }^{19}$ Publicada originalmente como tese pelo Museu Nacional/Universidade Federal do Rio de Janeiro UFRJ sob o título Araweté, uma visão de cosmologia e da pessoa tupi-guarani. Por estar acessível apenas em sua versão física no Museu Nacional, esta pesquisa utilizou a publicação em livro, de 1986, pela J. Zahar Editor: Associação Nacional de Pós Graduação e Pesquisa em Ciências Sociais.
} 
etnográficas e de tradução, as quais auxiliam significativamente a compreensão do canto, que está estruturado no formato pergunta-resposta e possui uma complexa situação enunciativa.

A década de 1990 observa não só um aumento do número de publicações comparativamente à década anterior, mas também um direcionamento do olhar dos tradutores e tradutoras de artes verbais Tupi-Guarani para os cantos, o que não havia ocorrido até então. É aberta com chave de ouro por meio de dois trabalhos de suma importância publicados nesse mesmo ano, ambos por antropólogos homens. Um deles é considerado o primeiro grande trabalho de etnomusicologia brasileiro, de autoria do etnomusicólogo Rafael José de Menezes Bastos. A festa da jaguatirica: uma partitura crítico-interpretativa (1990) foi publicada como tese em 1990 e mais de 20 anos depois como livro ${ }^{20}$, no qual traduziu 65 cantos (ressalto que essa é a publicação coletada na pesquisa contendo o maior número de cantos traduzidos), apresentados de forma bilíngue, letra seguida da tradução. É um trabalho de extrema importância para o estudo da música nas terras baixas sul-americanas, sendo considerado o primeiro exercício de descrição, transcrição e tradução da integralidade de um ritual musical ameríndio, o Yawari (“jaguatirica” em kamaiurá), que foi realizado em 1981 na aldeia dos índios kamaiurá (MENEZES BASTOS, 1989, p. 26). Menezes Bastos realizou a transcrição das letras das canções e, posteriormente, das músicas a partir do seu aprendizado do Yawari e das exegeses nativas feitas ainda em campo. A tradução das letras foi feita por ele com o auxílio de colegas e professores (Carl Harrison, Márcio Silva e Aurore Monod-Becquelin). O único comentário que faz a respeito do processo de tradução é curioso: “Traduzi as letras com muito medo: sou péssimo em linguística, pior em teoria literária e não sou poeta. [...] Há algumas traduções, entretanto, completamente tentativas. Na tradução das músicas, senti-me muito mais confortável" (ibid., p. 27). Como afirma o próprio autor, "o estudo das letras, incluindo sua tradução, é linguisticamente precário" (ibid., p. 231). Entretanto, esse não era seu objeto principal, mas sim as músicas em si, e este simples fato faz com que seu esforço de tradução de praticamente todas as canções que coletou seja reconhecido (das 68 canções que coletou, apenas três

\footnotetext{
${ }^{20}$ Esta pesquisa utilizou a publicação em livro, de 2019 (1ª reimpressão), pela Editora UFC.
} 
não foram traduzidas), visto que forneceu a outros pesquisadores a tradução de um ritual xinguano inteiro, contendo, além da letra (traduzida de forma bem literal), marcas de oralidade e de performatividade, como vocalização e repetições. É um material de pesquisa riquíssimo para aqueles que se interessam por tradução intersemiótica, principalmente pela possibilidade de diálogo com a própria tese desenvolvida por Menezes Bastos. De acordo com o etnomusicólogo, a música transforma verbo em corpo; ela é o pivô da cadeia intersemiótica do ritual, que entrelaça sistemas verbais, visuais e corporais. $\mathrm{O}$ ritual, por sua vez, é a máquina de transformar verbo em corpo. O ritual é o "tradutor".

O outro trabalho lançado no mesmo ano é A fala sagrada: mitos e cantos sagrados dos índios Guarani (1990)21, de autoria do antropólogo Pierre Clastres. A tradução da obra para o português foi feita pela tradutora Nícia Adan Bonatti, com publicação em 1990, sem a apresentação de comentários ou notas à tradução. O etnógrafo francês afirma que a obra trata de uma antologia (CLASTRES, 1990, p. 16), a qual contém dois textos em guarani ñandeva e 20 em guarani mbya, dividindo-se entre mitos e cantos. Os cantos correspondem a 10 deles, sendo que três são cantos-poemas referentes aos três primeiros capítulos do gênesis guarani Ayvu Rapyta, retraduzidos a partir das versões em castelhano feitas por León Cadogan, e sete correspondem a cantos também retraduzidos a partir de Cadogan. As traduções são todas monolíngues, acompanhadas por notas etnográficas e de tradução apresentadas em colunas à direita da página. Sua justificativa para o uso dessas notas é que o texto em versos busca uma "fidelidade à palavra" e precisa ser dissecado para que seja compreendido pelo leitor que não tem familiaridade com o pensamento guarani. Clastres demonstra sua preocupação em traduzir não apenas no nível linguístico, mas em alcançar, em suas traduções, a metafísica subjacente ao pensamento guarani.

Traduzir é, seguramente, tentar fazer passar para um universo cultural e lingüístico determinado a palavra e o espírito de textos saídos de um sistema cultural diferente, produzidos por um pensamento próprio. Quando, como nos mitos, o texto é uma narrativa de aventuras, a tradução não coloca problemas. O espírito cola-se, se assim podemos dizer, à palavra, o enigma é relativamente

\footnotetext{
${ }^{21}$ Publicada originalmente em francês sob o título Le grand parler - Mythes et chants sacrés des Indiens Guarani (Editions du Seuil) no ano de 1974.
} 
excluído na narração. Mais árduo, e por isso mesmo mais apaixonante, foi o trabalho de tradução dos textos religiosos. De maneira nenhuma por causa do uso constante que as Belas Palavras fazem da metáfora: basta saber que, quando o texto fala do "esqueleto da bruma", ele nomeia o cachimbo de barro onde os sábios fumam seu tabaco; que a "flor do arco" designa a flecha; que o nascimento de uma criança se diz "uma palavra se provê de um assento"; o embaraço do tradutor provém mais da dificuldade de dominar o espírito que corre secretamente sob a tranquilidade da palavra, de captar a embriaguez desse espírito que marca com seu selo todo discurso enigmático (1990, p. 17).

Sobre o Ayvu Rapyta, foi o objeto central da pesquisa de Clastres e, inclusive, foi o conjunto de cantos Tupi-Guarani mais retraduzido no período de 50 anos analisado. O Ayvu Rapyta é um conjunto de textos cosmogônicos e de ensinamentos religiosos dos Guarani Mbya do Paraguai. Estes cantos-mito são mantidos em segredo e, inclusive, são narrados em uma linguagem secreta de domínio apenas dos pajés, em que muitas vezes não há correspondência com a linguagem cotidiana. $\mathrm{O}$ pesquisador paraguaio León Cadogan, um exímio conhecedor da língua e do pensamento guarani, foi o primeiro a conseguir coletá-los e traduzi-los, graças à relação amistosa de vários anos que estabeleceu com os Mbya paraguaios e como retribuição por ter conseguido a libertação de um membro da comunidade que estava preso (CADOGAN, 1953, p. 36). Cadogan publicou esses textos pela primeira vez em 1946 na Revista de La Sociedad Cientifica del Paraguai sob o título Las tradiciones religiosas de los indios Jeguaká Tenondé Porángue del Guairá, comúnmente llamados Mbyá, Mbyá-Apyteré o K'ynguá, e continuou a publicar excertos e resumos de seu manuscrito em diversas revistas. A divulgação desse trabalho no Brasil teve início em 1953 por meio de uma iniciativa da Universidade de São Paulo (USP), a qual publicou os três primeiros capítulos - de um total de vinte - na Revista de Antropologia, num artigo intitulado Ayvu Rapyta: Textos míticos de los Mbyá-Guarani del Guairá (1953).

Como a produção do Ayvu Rapyta tem relação intrínseca com o tipo de relacionamento estabelecido entre Cadogan e os Guarani, é importante entender a trajetória de vida do pesquisador e a construção do seu relacionamento com a língua e a cultura guarani. A infância de Cadogan foi marcada pelo convívio direto com os povos indígenas e populações camponesas paraguaias, momento em que aprendeu o guarani e o inglês, mas muito pouco o castelhano, língua 
com que veio a ter contato efetivamente somente na escola primária. Sua formação educacional se deu, basicamente, de forma autodidata. Sua inquietude intelectual e suas investigações etnológicas e linguísticas resultaram em trabalhos intelectuais muito sistemáticos, baseados em coleta de dados quase obsessiva (RATTES, 2014, p. 26). Como filho de imigrantes socialistas, teve uma formação secular de um "livre-pensador", como se definia a si próprio (RATTES, 2014, p. 29). Após anos atuando com trabalhos diversos, aos 50 anos foi nomeado tutor indígena pelo governo paraguaio e pôde dedicar-se totalmente ao indigenismo, à antropologia e à linguística (Ayvu Raypta já havia sido finalizado nessa época, embora ainda inédito). Foi a partir do exercício desse cargo que conseguiu aprofundar uma relação de confiança com os Guarani, os quais o visitavam constantemente em sua casa.

A elaboração do Ayvu Rapyta, bem como de diversos materiais produzidos por Cadogan, deu-se a partir dessa relação próxima estabelecida com os Guarani, não apenas em termos de convivência, mas de produção intelectual conjunta. A transcrição de cantos e narrativas contava com a ajuda de indígenas, que repetiam os conteúdos do material coletado anteriormente e esclareciam expressões e conceitos desconhecidos. A primeira versão em papel era geralmente lida para especialistas, os xamãs mbya, que comentavam, corrigiam e acrescentavam informações ao que havia sido registrado. Segundo o antropólogo Kleiton Rattes, foi um trabalho efetivo de co-criação.

\footnotetext{
[...] como se vê em seus manuscritos, boa parte daquilo que L. Cadogan editou e publicou, foi posteriormente reformulada, por ele próprio, com novos dados, outras transcrições e diferentes caminhos tradutivos a partir de novas pesquisas e novos momentos de revisão dos dados em parceria com os índios. Uma oficina poética, um ateliê da palavra, cuja pena de L. Cadogan foi guiada por ele, pela boca dos intelectuais mbya, como também pela astúcia, destreza e disposição de outros indígenas que lidavam com a materialidade dos dados linguísticos, míticos e metafísicos dos mbya. A presença nativa era entendida como presença de intelectuais co-criadores de seus trabalhos, pois os índios não eram somente vistos como informantes, insulados em um tempo e um espaço dados (o outrora lá naquele alhures do campo), mas como pensadores ativos na criação do conhecimento de modo multissituado, temporal e espacialmente. Quero dizer, agentes que estiveram presentes no momento inicial da primeira coleta, escuta das palavras indígenas proferidas pelos mburuvicha, mas que retornaram em outros momentos e em espaços diferentes para corrigir, acrescentar, repetir, esclarecer a respeito dos materiais disponíveis. Índios, com nomes próprios e
} 


\begin{abstract}
lugares, que repetiam para L. Cadogan conceitos e orações que outrora havia coletado, esclareciam noções e expressões desconhecidas, ajudavam na morfologia do trabalho de transcrever. Este é o caso dos célebres textos de Ayvu Rapyta, cujo corpus é devedor dos saberes do xamã Pablo Vera, mas que foi retrabalhado, em um segundo (terceiro, quarto...) momento, com a ajuda de outros Mbya, na transcri(a)ção, na explicação, na tradução e nos acréscimos (RATTES, 2014, p. 60).
\end{abstract}

Dois anos depois dessas duas publicações que marcaram os estudos antropológicos sobre cantos ameríndios, surge a primeira publicação na área literária, Palavras Canibais (1992), do escritor e tradutor Antônio Risério. Ele retraduz O Canto da Castanheira em 1992 em seu artigo Palavras Canibais, publicado na Revista USP, republicado um ano depois como capítulo do livro Textos e tribos: poéticas extraocidentais nos trópicos brasileiros (1993).

Após oferecer uma explicação sobre o que significa linguagem e palavra - ou palavra-canto, nos termos do autor - entre os Araweté e discorrer sobre seus dois gêneros "poemusicais", baseado na etnografia de Viveiros de Castro, Risério trata especificamente do Canto da Castanheira e apresenta sua versão do canto. Basicamente, o autor faz apenas algumas alterações na versão de Viveiros de Castro ${ }^{22}$, "abrasileirando os nomes das personagens (em função tanto do 'estranhamento' quanto do estrato sonoro do texto), enxugando algumas frases, procurando acumular determinados grupos fonéticos (nasais, por exemplo) etc., mas sem arriscar muito no jogo" (1992, p. 41), visto que Viveiros apresenta uma versão etnográfica bem detalhada. Faz comentários rápidos sobre suas escolhas tradutórias antes de apresentar a tradução ao final do texto. Em nosso entendimento, o texto se destaca não tanto pela tradução apresentada, mas pela reflexão produzida por Risério sobre a atualidade das poéticas indígenas e sobre as especificidades que permeiam esse tipo de texto, como a performatividade, a parataxe, entre outros aspectos, tanto em nível linguístico quanto metafísico.

A última publicação desta década de 1990 é Soninho com pios de periquitos ao fundo (1996), de autoria de Josely Vianna Baptista e Luli Miranda. Corresponde ao segundo volume da série Cadernos da Ameríndia e é um livro infantil, no qual as autoras traduzem uma canção de ninar (a única do corpus

${ }^{22}$ Segundo o próprio Risério, “o que o leitor vai ler é, fundamentalmente, a versão de Viveiros” (1992, p. 41). 
todo) gravada por estudantes da Faculdade de Antropologia da Universidad Nacional de Misiones, Argentina, nas noites de 21 e 22 de setembro de 1979. O escritor Carlos Gamba relata ter ouvido essa canção em suas andanças pelo deserto do Chaco paraguaio para conversar com indígenas. Segundo as tradutoras, Gamba afirma que essa canção foi ouvida e anotada por Cadogan no Paraguai antes de ele morrer. Baptista e Miranda declaram que há apenas uma pequena diferença entre uma canção e outra, mais especificamente nos dois primeiros versos. A canção é apresentada em formato bilíngue.

Após duas décadas, a atividade de tradução de cantos Tupi-Guarani tornou-se mais variada em termos de línguas-fonte, mas com a antropologia ainda dominando este campo de pesquisas. $\mathrm{O}$ ponto de maior destaque nesta década de 2000 é surgimento de tradutores indígenas no cenário da tradução de cantos, um deles figurando, inclusive, como autor da publicação da qual as traduções fazem parte.

Esta nova década começa bem representada por meio da publicação Nhande Reembypy: Nossas Origens (2001), organizada pelo linguista e antropólogo Wilson Galhego Garcia e publicada pela Universidade Estadual de São Paulo - UNESP/Faculdade de Ciências e Letras/Centro de Estudos Indígenas "Miguel A. Menéndez". Nela, Garcia conseguiu compilar 31 cantos guarani kaiowá, além de 274 narrativas; uma obra louvável por sua extensão. A coleta dos cantos ocorreu durante um longo período de 15 anos (1974 - 1989) entre os Kaiowá de Amambai, Mato Grosso do Sul. A pesquisa de campo inicial tinha como objetivo coletar informações referentes ao universo botânico kaiowá. O pesquisador teve então a ideia de tornar o material acessível aos Kaiowá e a pesquisa etnobotânica inicial transformou-se num projeto de catalogação de tradições orais. Foram dezenas de horas de gravações de assuntos relativos a cantos rituais e profanos, mitos de origem, religião, parentesco, plantas, animais, cores, aspectos da vida cotidiana, entre outros. Todo o material foi gravado e, posteriormente, transcrito e traduzido literalmente para o português pelo tradutor kaiowá Aniceto Ribeiro, o qual foi treinado por Garcia segundo a metodologia do Summer Institute of Linguistics (SIL) - atualmente, Sociedade Internacional de Linguística. As gravações foram feitas em campo e quase sempre diante da situação objeto do texto, ou seja, um casamento, um nascimento, um enterro, e assim por diante. De acordo com o pesquisador, Aniceto gravou as 
declarações e as traduziu sem as interpretar; por isso, os dados seriam, realmente, "neutros"23. Para a publicação, foram respeitados a grafia e o estilo originais de Aniceto, tanto em kaiowá quanto em português (GARCIA, 2001, p. 12). Se a iniciativa de um trabalho dessa grandeza já é louvável por si só, quanto mais o fato de ter sido traduzida integralmente por um tradutor indígena, devidamente treinado. Isto é raro, mas deveria ser a regra - ou, pelo menos, ser mais recorrente no trabalho de tradução de artes verbais indígenas. No prefácio do livro, o jesuíta e antropólogo guaraniólogo Bartolomeu Meliá tece o seguinte comentário sobre Aniceto: "Aniceto é um homem que deve ser retido como etnógrafo dos seus povos" (GARCIA, 2001, prefácio, s.n.).

No mesmo ano, o escritor indígena Kaká Werá Jecupé24 publica Tupã tenondé: a criação do universo, da terra e do homem segundo a tradição oral Guarani (2001) pelo Instituto Arapoty ${ }^{25}$ em parceria com a Editora Fundação Peirópolis, no qual faz uma retradução dos quatro primeiros capítulos do Ayvu Rapyta a partir da versão guarani-castelhano de Cadogan. Apresenta os cantos em formato bilíngue, os quais são acompanhados de comentários sobre determinados termos segundo o pensamento e a metafísica guarani. É a primeira obra do levantamento desta natureza publicada por um indígena.

Continuando a tradição antropológica de pesquisa de cantos indígenas e dando força ao campo da etnomusicologia americanista, Deise Lucy Oliveira Montardo publica sua tese Através do Mbaraka: música e xamanismo Guarani (2002), a qual é uma etnografia que teve como objeto de análise a música guarani executada no ritual cotidiano realizado pelos Guarani, denominado jeroky nos subgrupos Kaiowá e Nandeva (Mato Grosso do Sul), e purahéi nos subgrupos

\footnotetext{
${ }^{23}$ Aspas minhas. As contínuas discussões nos Estudos da Tradução já mostraram que o ato de traduzir envolve um posicionamento de ordem subjetiva do tradutor, que tem ligação com suas opiniões, visão de mundo, entre outros fatores, que influenciam e determinam suas escolhas tradutórias. Então, afirmar que transcrições e traduções são neutras é, de fato, questionável.

${ }^{24}$ Kaká Werá (nome pelo qual é conhecido) nasceu em Parelheiros, periferia de São Paulo, local que abriga duas aldeias guarani. Seus pais vieram de Minas Gerais e passaram pelo processo de negação de sua identidade indígena em razão de preconceito. Assim, Kaká Werá veio a se reconhecer como indígena apenas durante o colegial e, hoje, identifica-se como Txucarramãe (um dos clãs Kayapó). Transformou-se em educador e possui um longo trabalho de difusão das culturas indígenas, seja por meio do trabalho com educação, seja por meio da literatura. Possui diversos livros publicados.

${ }^{25} \mathrm{O}$ Instituto Arapoty é uma organização sem fins lucrativos fundada em 1998 por Kaká Werá com o objetivo de difundir as tradições indígenas para jovens e ajudar aldeias do sul e do sudeste do país a trabalharem de forma sustentável. Sua sede está localizada em Itapecerica da Serra, estado de São Paulo.
} 
Mbya e Chiripá (sul e sudeste do Brasil). Montardo apresenta a tradução bilíngue de 15 cantos, dos quais 13 são kaiowá e dois são ñandeva (cantos 8 e 9). Eles estão descritos no capítulo 2 da tese, chamado “Descrição da dança e da música nos rituais kaiová (ibid., p. 61 e seguintes). A etnomusicóloga trabalha com as traduções que obteve de intérpretes nativos e as complementa com comentários resultantes de exegeses e de consultas a dicionários, "num esforço analítico que visa a ampliar a compreensão do texto". Contou também com a ajuda do linguista Wilmar D' Angelis e da guaranióloga Friedl Grünberg (ibid., p. 74). Montardo faz comentários sobre suas escolhas tradutórias, com uma discussão muito interessante sobre a dificuldade de se acessar o valor dos termos nativos segundo a perspectiva ontológica guarani, devido ao tipo de tradução realizada pelos intérpretes, que utiliza os termos aprendidos com os missionários:

\begin{abstract}
Os Guarani dominam a tradução feita nas fontes históricas e trabalham com elas ao informarem os antropólogos. Não pude obter uma tradução lingüística analítica. Todos os materiais e a ajuda que obtive de lingüistas foram baseados no dicionário de Cadogan, um clássico de inegável valor, mas que, para uma tradução analítica, às vezes não é suficiente. Se me baseio na tradução nativa, estou trabalhando com a tradução da tradução, e para destrinchá-la teria que reler com critério as fontes históricas e pensar em todo o processo de construção da tradução. Trabalho a que se propôs Cristina Pompa (2001), ao fazer uma análise histórico-antropológica do processo de encontro entre indígenas e missionários no Brasil colonial e que fornece muitas pistas para pensar e questionar as traduções do guarani com as quais trabalham a literatura e os próprios Guarani.

A autora explicita que houve uma negociação constante nas traduções feitas no processo das missões, 'em que os símbolos de um e de outro constituíram uma linguagem de mediação' (2001:iii). Exemplo destas idas e voltas de traduções é o uso de Tupã para designar Deus ou Jesus Cristo (ibid., p. 28-29).
\end{abstract}

Também na antropologia, é publicado Os Kaiabi do Brasil Central: história e etnografia (2004), de autoria do antropólogo Georg Grünberg. É uma etnografia (contendo não apenas cantos mas também narrativas) e publicada originalmente em formato de tese e em língua alemã, em Viena, Áustria, como resultado da pesquisa realizada por ele durante sua viagem de campo entre os Kaiabi do Rio dos Peixes, noroeste do Mato Grosso, de dezembro de 1965 a novembro 1966, sob orientação do etnólogo Herbert Baldus. Desde então, circularam poucas cópias datilografadas em versão traduzida por Thekla 
Hartmann (que, inclusive, revisou a tradução da publicação usada nesta pesquisa) e Eugênio Wenzel; a tradução para o português foi finalmente publicada em 2004. O texto original foi traduzido integralmente, com exceção do capítulo V (Cultura Material), substituído pelo próprio autor por uma versão maior e mais completa, publicada originalmente por Fiedl e Georg Grünberg em 1967 e traduzido para o português por Thekla Hartmann em 1997. Observo que, durante o trabalho de campo na década de 1960, as partes narradas em língua kaiabi foram traduzidas para o português por intérpretes indígenas e Grünberg fez a tradução posterior para o alemão. Quase quatro décadas depois, a obra em alemão foi novamente traduzida para o português. Nessa publicação, há dois tradutores, Eugênio G. Wenzel, responsável pela tradução da etnografia, e o padre João Dornstauder, tradutor dos cantos.

Especificamente sobre os cantos coletados por Grünberg, foram narrados pelo cacique Temeoni, em kaiabi, mas gravados e traduzidos para o português pelos tradutores kaiabi Piaka e Nawé (assim, mais um caso de tradução feita exclusivamente por tradutores indígenas). A escolha de Temeoni como o informante em língua kaiabi justifica-se pelo fato de que "talvez fosse o único a ter plena consciência da amplitude da catástrofe sofrida pelos Kaiabi desde seu contato com os brasileiros. Ele se negava até a pronunciar uma única palavra em português". Grünberg conclui, dizendo estar convencido de que "[...] Temeoni constitui o melhor fornecedor de informações abrangentes sobre a cultura Kaiabi, mas para assim utilizá-lo, o domínio da língua é conditio sine qua non" (ibid., p. 21).

Essa década fecha com mais uma etnografia. Terra madura, yoy araguyje: fundamento da palavra Guarani (2008) de Graciela Chamorro, publicada pela Editora da Universidade Federal da Grande Dourados (UFGD), aborda a relação entre a religião indígena original e o cristianismo entre os Guarani Mbya, Kaiowá e Nandeva. Apresenta nove cantos traduzidos em formato bilíngue, dos quais dois são retraduções. Os cantos traduzidos por Chamorro são: uma reza ou "jerosy puku ou ñembo'e puku”, "o longo canto-dança" ou "a longa reza" (ibid., p. 243); dois cantos mais melódicos e que mais se aproximam do padrão musical ocidental (ibid., p. 246); e quatro outros cantos sem definição mais específica dada pela autora (ibid., p. 267-270). Já as retraduções são feitas a partir de dois cantos apresentados no CD Memória Viva 
Guarani, um registro de cantos e músicas da tradição dos índios Guarani, entoados por 11 corais infanto-juvenis, compostos por mais de 200 crianças e jovens das aldeias Krukutu, Tenondé Porã, Tekoa Pyau, Sapukai, Boa Vista, Rio Silveira, Itaoca, Rio Branco, Piaçaguera, Pindoty e Peguaoty, localizadas em São Paulo e Rio de Janeiro ${ }^{26}$. Chamorro apresenta uma nova versão dos cantos $O$ sol e De onde procedes? (ibid., p. 247), a partir de modificações nas traduções contidas no encarte do CD.

A quinta e última década abordada na pesquisa é, sem dúvida, a de maior destaque em número de traduções publicadas. A partir de 2010, as traduções para o português de cantos Tupi-Guarani despontam no cenário das artes verbais ameríndias no Brasil, registrando mais do que o dobro de publicações em comparação à década de 2010. É o período de maior variedade de tipos de publicações (livros, artigos, teses e até um documento resultante de projeto de documentação linguística). Quanto às áreas do conhecimento de onde partem as iniciativas, estão mais variadas do que na década anterior, com publicações na área da antropologia, linguística, literatura e educação. Os projetos de documentação linguística entram com mais força nesse cenário $(O$ Grupo LEETRA/UFSCAR lança uma publicação e o PRODOCLIN/Museu do Índio lança duas) e as mulheres, indígenas e não indígenas, dominam a produção de traduções em áreas do conhecimento variadas.

Duas publicações, uma da área da antropologia e outra da linguística, abrem a década de 2010. Em Karawara: a caça e o mundo dos Awá-Guajá (2010), o etnógrafo Uirá Fellipe Garcia apresenta uma etnografia dos Guajá (MA), publicada como tese pelo Programa de Pós-Graduação em Antropologia Social da Universidade de São Paulo - USP, na qual traduz três cantos apresentados em formato bilíngue, os quais se referem "diretamente à presa que o karawara, dono do canto, caça. Por isso, são também cantos de caça, entoados pelos Awá quando vão caçar (baixinho para não serem ouvidos) e, principalmente, quando retornam (bem alto para que todos saibam que animal abateram)" (2010, p. 401). Segundo o antropólogo, os Guajá [também conhecidos como Awá Guajá ou apenas Awá] são um povo fundamentalmente caçador, e a

\footnotetext{
26É possível ouvir as músicas no site de venda oficial do CD: http://www.mcd.com.br/memoria-vivaguarani/.
} 
tese tem como objeto as relações que se estabelecem entre as atividades de caça e outros processos de vida.

Garcia discute ao longo de toda a etnografia sobre escolhas de tradução, seja por parte dos Guajá, seja por ele (e, em alguns momentos, discute inclusive as escolhas terminológicas de outros pesquisadores). Um comentário que faz logo no início da tese é:

\begin{abstract}
Nos insuficientes nove meses que passei entre os Awá, para me explicarem os fatos de 'seu mundo', as pessoas gentilmente se utilizaram de imagens do 'meu mundo' (como torneiras, espelhos e motores), para que eu entendesse suas explicações. Boa parte desta tese é baseada em explicações que me foram fornecidas nestas formas transnominadas, que em alguns momentos, como agora, eu não poderei escapar de transcrever fielmente. Como a etnologia é fundamentalmente um trabalho de tradução, muitas das que proponho aqui começaram com eles (ibid., p. 40).
\end{abstract}

Garcia comenta sobre sua dificuldade de traduzir os cantos por causa das especificidades inerentes a esse tipo de arte verbal guajá. Diz ele que "[...] traduzir esses cantos é uma tarefa ainda por fazer, pois diferente das narrativas, o canto parece falar em um outro idioma, muitas vezes com gemidos e vocalizes que ocultavam totalmente as palavras" (ibid., p. 401). Afirma que foi algo impossível, principalmente nos contextos do dia a dia, e que as pouquíssimas traduções que realizou foram em forma de "aulas de canto", que lhes foram ministradas para que pudesse participar dos rituais da takája. Em nota, acrescenta:

\footnotetext{
As minhas tentativas de tradução com intérpretes sempre foram mal sucedidas. No início, como num rompante etnocêntrico (dentre tantos outros que experimentei no campo) achava que tratava-se de má vontade do tradutor, já que perdíamos por vezes horas e não saíamos do lugar. E pensei que se "pagasse" pelo serviço adiantaria (com meus objetos e coisas que tinha guardados comigo, como facas, cordas, isqueiros e o que mais eu tivesse). Mas, mesmo "pagando", não houve diferença na (pensava eu) "má vontade" dos tradutores. Foram tantas as confusões semânticas que decidi parar com as traduções formais. Para que eu traduzisse algumas canções, foi necessário realizar traduções internas à língua, do formato musical para o oral, e depois tentar traduzir para o português (ibid., p. 401).
} 
Já a outra publicação é uma coletânea organizada pelo projeto de Documentação de Línguas Indígenas PRODOCLIN/Museu do Índio, coordenado pela linguista Suzi Lima. Textos produzidos pelos Kawaiwete (anos 2010 e 2011): poemas/músicas e materiais tradicionais Kawaiwete (2010) contém duas canções bilíngues, além de outros textos. O material é resultado de atividades de escrita realizadas durante três oficinas (jul/2009; dez/2009; jul/2010) entre os Kaiabi (também conhecidos como Kawaiwete). Contou com a participação de 33 autores kaiabi, que provavelmente foram também os tradutores. Infelizmente, não há informações quanto ao gênero e ao número de tradutores participantes.

A escritora tradutora Josely Vianna Baptista aparece novamente, desta vez com Roça barroca (2011), no qual retraduziu os três primeiros capítulos do Ayvu Rapyta, de Cadogan, dez anos após a retradução de Kaká Werá Jecupé. Foi publicado pela Cosac Naify. A tradução se deu a partir do original em guarani e da leitura da tradução em espanhol feita por Cadogan, utilizando diversas obras de referência para um entendimento das palavras em mbya. Durante o processo de tradução, Baptista descreve que fez primeiramente uma tradução unilateral dos cantos; depois, atenta aos elementos formais do original, fez uma retradução em busca de "compensações possíveis" para que fosse possível alcançar uma eficácia poética em português. Também, contou com o auxílio de Teodoro Tupã Alves, liderança indígena e professor da aldeia de Ocoy, localizada em São Miguel do Iguaçu, Paraná, o qual entoou os cantos em mbya e Josely os gravou para perceber as modulações e tessituras sonoras (ibid., p. 12). A versão de Baptista prezou, acima de tudo, a forma, "num exercício escritural em que tentei infundir no português um pouco do 'sussurro ancestral' da língua guarani" (ibid., p. 13). Além das traduções, inclui comentários relacionados ao processo de tradução no capítulo Breve Elucidário.

Outra tradutora não indígena também faz sua segunda publicação sobre cantos Tupi-Guarani. Graciela Chamorro desta vez publica 13 cantos bilíngues em $A$ arte da palavra cantada na etnia Kaiowá (2011), artigo que trata das formas da palavra cantada kaiowá, publicado pela revista Société Suisse des Américanistes/Schweizerische Amerikanisten - Gesellschaft, no qual apresenta três modalidades de cantos: a reza, o canto lamento e o canto de encontro. A traduções são acompanhadas de descrições sobre o contexto e as formas em que 
esses gêneros ocorrem nas comunidades kaiowá, buscando, assim, distingui-los de seus homônimos nas comunidades mbya e ñandeva. Dos 13 cantos, 11 são kaiowá e dois são ñandeva.

O Canto da Castanheira ganha nova retradução, desta vez pelas mãos do poeta, tradutor e professor da Universidade de São Paulo (USP) Álvaro Faleiros. Em Emplumando a grande castanheira (2012), artigo publicado pela Revista de Estudos Avançados, Faleiros ofereceu uma retradução do Canto da Castanheira revista à luz do perspectivismo ameríndio. $\mathrm{O}$ artigo trata da complexidade do agenciamento enunciativo de que fala Viveiros de Castro em sua tese ao abordar os cantos xamanísticos dos Araweté. Inicialmente, Faleiros detalha essa complexidade enunciativa descrita no Canto da Castanheira e, num segundo momento, comenta as traduções de Antônio Risério e Viveiros de Castro. Especificamente sobre a tradução feita por Risério, diz que " [...] a intenção de Risério é boa, no sentido de ampliar a espectro daquilo que compõe o espaço de uma poética brasílica [...]. A questão é que as consequências de sua postura semiótico-textual produzem uma tradução, a meu ver, discursivamente opaca" (ibid., p. 61-62). Sendo assim, apesar de Risério ressaltar as especificidades da poética araweté, na opinião de Faleiros, ele opera totalmente dentro da lógica textual das poéticas ocidentais quanto à organização textual proposta - "a 'forma poema' é reconhecível, codificável" - e o próprio valor poético de sua tradução fica comprometido, visto que depende de todo um arcabouço etnográfico exterior ao texto (ibid., p. 62). Faleiros, então, apresenta sua retradução ao canto araweté, antecedido de alguns comentários relacionados à postura tradutória que assume. Adota três tipos de notas: notas performativas, notas relacionadas ao universo simbólico araweté e notas para marcar os movimentos enunciativos do texto; inclui também alguns "epítetos" no corpo do texto para explicitar as relações de parentesco os personagens e ressalta os aspectos poéticos do texto, como os paralelismos, repetições e sonoridades. O autor desenvolve nesse artigo a proposta de uma teoria xamânica da tradução. Traduzir cantos ameríndios, para ele, é concebido como um "jogo de relações entre formações discursivas diferentes", uma forma discursiva que leva em conta as diferentes ontologias e que "coloque em relação os universos simbólicos e os modos de construção de sentido do que difere" (ibid., p. 63). 
No mesmo ano, Eunice Dias de Paula publica sua tese de doutoramento em Letras e Linguística pela Universidade Federal de Goiás (UFG), Eventos de fala entre os Apiãwa (Tapirapé) na perspectiva da etnosintaxe: singularidades em textos orais e escritos (2012), na qual apresenta, na parte dos anexos, a tradução bilíngue de três cantos tapirapé colhidos durante pesquisa de campo realizada em dezembro de 2010. Os cantos foram traduzidos pela autora e chamam-se Canto convocatório ritual relacionado à refeição de Espíritos, Canto do Ka'orete e Canto do Gavião Real.

Mais uma coletânea organizada pelo projeto de Documentação de Línguas Indígenas PRODOCLIN/Museu do Índio é lançada, desta vez dedicada exclusivamente a cantos. Yafu: o retorno do chocalho (2014) contém 27 cantos kaiabi em formato bilíngue, produzidos a partir da revitalização da festa Yafu:

\begin{abstract}
A festa foi retomada a partir do sonho do pajé e cacique da aldeia, chamado Gwarujá, Tuiaraiup Kaiabi, sonho no qual ele visualizou os desenhos gráficos, os objetos a serem usados, assim como as músicas que foram gravadas durante a festa realizada na aldeia Gwarujá, em 2011. A festa foi fundamental para que os Kawaiwete retomassem cantos e danças tradicionais. Hoje, as músicas do Yafu são constantemente ouvidas entre os Kawaiwete do Xingu, que, criativamente, usam as suas melodias para compor novas letras que contemplem questões para eles atualmente relevantes, como educação, saúde e direitos (ibid., p. 14).
\end{abstract}

A transcrição do conteúdo oral em texto foi feita durante uma oficina realizada em 2011 na aldeia Tuiararé como parte das atividades do PRODOCLIN/Kawaiwete. O material foi transcrito e traduzido pela coordenadora Suzi Lima e quatro tradutores kaiabi: Aturi (Jowosipep) Kaiabi e Piruruk Kayabi, professores e principais tradutores, e Tomãiru Kaiabi e Wyrakatu Kaiabi. Segundo informa Lima, as canções foram traduzidas levandose em conta as especificidades dos cantos indígenas, como a repetição.

Os Araweté ganham outro trabalho antropológico com a publicação da tese de Guilherme Orlandini Heurich, Música, morte e esquecimento na arte verbal Araweté (2015), defendida pelo Programa de Pós-Graduação em Antropologia Social do Museu Nacional/Universidade Federal do Rio de Janeiro - UFRJ, na qual apresenta uma análise da arte verbal araweté por meio de seus aspectos formais e semânticos. Heurich traduz 24 cantos araweté coletados por 
ele, dos quais 14 relacionam-se à festa da cauinagem. Quanto ao processo de tradução, foi acompanhado em boa parte pelos Araweté, mas o material produzido é resultado especificamente do trabalho de Heurich com os intérpretes Jatomaro e Irarũno - principalmente com o segundo, com quem pôde traduzir por mais tempo e, consequentemente, em maior quantidade (ibid., p. 38-39). A partir das traduções, o autor pôde traçar características gerais das artes verbais araweté.

Outro programa de documentação linguística entre em cena. $\mathrm{O}$ Laboratório de Linguagens LEETRA, da Universidade Federal de São Carlos (UFSCar), publica Nheengatu Tapajoara (2015), um material didático (o único do corpus) publicado como edição especial da revista LEETRA Indígena. Foi construído em conjunto com os professores indígenas de Santarém/PA (LABORATÓRIO DE LINGUAGENS LEETRA, 2015b, p. 7) e reuniu dez cantos traduzidos referentes a cantos tradicionais e de composições atuais, além de narrativas nheengatu.

Já em 2017, um livro direcionado especialmente à educação musical é publicado pela Editora Peirópolis. Em Cantos da Floresta: iniciação ao universo musical indígena (2017), organizado por Magda Pucci, etnomusicóloga e musicista do grupo Mawaca, e Berenice Almeida, musicista e educadora musical, é feita a reunião de 27 cantos de vários povos ameríndios, dos quais cinco são em línguas Tupi-Guarani: dois cantos em guarani kaiowá, um canto em nheengatu e um canto em kambeba. Os cantos estão disponibilizados no site de divulgação do livro27.

O primeiro canto guarani kaiowá chama-se Ñande mbaraete'i katu / Vamonos fortalecer e é uma versão do grupo musical guarani Kyringue Arandu Mirĩ, da Aldeia Rio Silveira, São Paulo. Sua transcrição e tradução foram extraídas pelas autoras do encarte do CD Ñande Arandu Pyguá:

\footnotetext{
É um canto usado para fortalecer o espírito e o corpo das crianças e assim trazer alegria. Como em várias músicas Guarani Mbya, o mbaraka (violão) tem a função percussiva de marcar o pulso junto aos mbaraka mirĩ (chocalhos de mão) de forma regular. É interessante observar que o violão se mantém como um pedal, não faz mudanças de acordes, pois sua função é marcar a subdivisão do compasso binário. A introdução é feita pela ravé (rabeca) que toca a melodia do
}

\footnotetext{
${ }^{27} \mathrm{O}$ endereço do site é <http://www.cantosdafloresta.com.br/>.
} 
canto com pequenas variações. É importante notar que o timbre das vozes das crianças Mbya se destaca pela sonoridade nasalada, aberta e vibrante. Portanto, ao interpretar esses cantos em outros contextos, seria interessante manter essa característica timbrística (PUCCI; ALMEIDA, 2017).

O segundo canto kaiowá chama-se Maimo oimẽ nde rori/Onde está sua alegria? e foi transcrito e traduzido pela antropóloga Graciela Chamorro (terceira obra nesta pesquisa em que Chamorro aparece). Refere-se ao tekoha e faz parte do repertório da comunidade kaiowá de Itay, próximo a Dourados, Mato Grosso do Sul. É um canto criado recentemente, durante o processo de revitalização cultural e resistência que vem marcando a vida dos Kaiowá da região. "Cantada em uníssono, a música tem duas frases que se repetem com um ritmo 'swingado' impresso pelas antecipações rítmicas" (ibid., 2017).

O canto em nheengatu tem o título Murukutu/Coruja da noite. É uma cantiga de ninar que se refere à coruja murukutu, figura simbólica relacionada à cosmogonia dos povos da Amazônia, com uma sonoridade bem específica, marcada por forte nasalidade e exploração da vogal $u$. É de origem arapaso, da Comunidade Taracuá, e foi traduzido pelo tradutor e pesquisador Marcel T. Ávila.

Os dois últimos cantos são de origem kambeba e foram transcritos e traduzidos por Márcia Wayana Kambeba. O primeiro se chama Ataware tó/Canto da galinha e é uma brincadeira infantil realizada com a galinha inambu, bem comum na região, que costuma cacarejar de hora em hora. Segundo as autoras, o "tuxaua [chefe], os professores e as crianças chamam pela ave, dançando em círculos, de mãos dadas e dando pequenos saltos. O canto é intercalado com “conversas do tuxaua com a galinha, perguntando-se onde ela está" (ibid., 2017). O segundo canto kambeba chama-se Zana makatipa, Kurupira/Tuxaua, cadê a Curupira? e, como o próprio nome diz, refere-se àquele ser mitológico. Segundo os Kambeba, o Curupira pode ser um menino ou uma menina pequena de cabelos vermelhos e com os pés virados pra trás, ou ainda apresentar-se na versão de casal, formado por uma figura feminina e outra masculina. Pode, ainda, apresentar-se como vítima ou como um ser ameaçador. $\mathrm{Na}$ versão do canto apresentada aqui, Curupira está em sua forma feminina. De acordo com as organizadoras, é interessante observar que “a melodia de Zana Makatipa, 
Kurupira é semelhante à da canção infantil de origem portuguesa ' $A$ machadinha', revelando a história dos próprios Kambeba, que tiveram um contato intenso com os colonizadores ibéricos".

Fechando o corpus e a década de 2010, temos Viver na língua Guarani Nhandewa (mulher falando) (2018). Trata-se da dissertação de Sandra Benites, apresentada no Programa de Pós-Graduação em Antropologia Social do Museu Nacional/Universidade Federal do Rio de Janeiro (UFRJ), que teve como objetivo analisar as desavenças e conflitos entre a tradução e a educação Guarani imposta nas aldeias como escola formal, utilizando-se do conceito de "bilinguismo" como ferramenta. Apresenta a tradução de dois cantos-danças relacionados à Dança do Tangará, a qual é praticada até hoje pelos Ñandeva e serve para a preparação de corpos saudáveis. Suicídios são comuns em aldeias onde essas danças não são mais praticadas (ibid., p. 88). A primeira tradução foi feita por Maria Kerexu ${ }^{28}$ [possivelmente a esposa do escritor Olívio Jekupé] e transcrita pela autora (ibid., p. 87). A segunda foi feita pela própria autora (ibid., p. 87-88). Ambas são apresentadas em formato bilíngue.

Ao longo da dissertação, a antropóloga, de origem ñandeva, discute como a tradução não se trata apenas da transposição linguística de uma língua para outra e, como sempre, envolve conflitos de poder: "Teríamos de estar equipados para dois mundos, mas esses equipamentos teriam de ser algo que chegue próximo, de modo a traduzir conhecimentos entre dois mundos. Até hoje, enfrentamos vários obstáculos para experimentar essa aproximação e essa tradução" (ibid., p. 59).

\section{Apontamentos finais}

Apresentamos uma amostra bem específica, com foco apenas em cantos com origem em línguas Tupi-Guarani e num recorte temporal de 50 anos, de uma pesquisa conduzida por apenas uma pesquisadora num intervalo de dois anos e meio e, mesmo assim, foi possível coletar 233 cantos traduzidos. Se considerarmos as possibilidades de pesquisa e tradução envolvendo outras

\footnotetext{
${ }^{28} \mathrm{~A}$ tradução faz parte do trabalho de conclusão de curso de Maria Kerexu. Referência: KEREXU, Maria Cecília Barbosa. A vida do pássaro, o canto e a dança do tangará. Trabalho de conclusão de curso (Licenciatura intercultural indígena em História) - Universidade Federal de Santa Catarina, Florianópolis. 2015. 30p.
} 
famílias linguísticas e períodos históricos, a potência que este campo de estudos pode adquirir é enorme.

Gostaríamos de ressaltar a relevância da aplicação de gerenciadores bibliográficos em metodologias focadas em realizar uma arqueologia da tradução. Nesta pesquisa, utilizamos o Zotero, mas existem muitos outros, adaptados para diferentes sistemas operacionais e com recursos dos mais variados. Seu uso em pesquisas que tenham um caráter de levantamento e que busquem realizar uma arqueologia da tradução a partir de grandes dados bibliográficos pode ser muito eficaz tendo em vista as múltiplas possibilidades de combinação de objetos de estudo (loci circunstanciais) que oferece. Viabiliza significativamente a pesquisa que pretende trabalhar com muitas variáveis ao mesmo tempo e, consequentemente, a construção de mapeamentos de grande amplitude e alcance.

O corpus apresentado fornece alguns insights relacionados à aspectos do pensamento e da metafísica ameríndia que podem ser utilizados para começar a se investigar não só uma possível teoria da tradução de cantos Tupi-Guarani, mas de cantos e artes verbais como um todo. As artes verbais ameríndias ainda estão em processo de reconhecimento como um campo de estudos específico. $\mathrm{Na}$ verdade, a discussão sobre o estatuto que devem adquirir as formas de expressão verbal indígenas ainda encontra vozes bem distintas entre aqueles que lutam em defesa da adoção do termo literatura e entre aqueles adotam uma posição contrária ou diferenciada. É uma escolha que tem origem em uma longa discussão sobre opções terminológicas feitas por estudiosos que têm se dedicado à tradução de poéticas ameríndias no Brasil. Em Concepts and Contests in the Translation of Indigenous Poetics in Brazil (2015), a tradutora e pesquisadora Jamille Pinheiro Dias discorre de forma elucidativa acerca desse tema. Resumidamente, Cláudia Neiva de Matos, seguindo Paul Zumthor, afirma sua preferência pelo termo "arte verbal", visto que admite usos artísticos tanto da língua oral quanto da língua escrita, sem favorecer a segunda, bem como pelo termo "poesia", por ser uma arte da linguagem humana, fato da ritualização da linguagem. Lucia Sá, por sua vez, entende que excluir textos nativos da categoria "literatura" pode ter efeitos negativos, uma vez que as "literaturas da floresta" devem ser vistas mais do que apenas material etnográfico, material bruto ou, de forma particularmente depreciativa, como mito. Já Marília 
Librandi-Rocha, em sua exposição sobre a carta Guarani-Kaiowá, defende a inclusão dos textos indígenas como parte da essência da literatura escrita no Brasil, considerando o direito à literatura como território discursivo acolhedor. Em direção oposta à Librandi-Rocha, Marco Natali defende exatamente o direito de não ser literatura ao criticar a "inevitabilidade" da aplicação do conceito literatura e a forma que ele incorpora práticas discursivas não europeias ${ }^{29}$. Jamille Dias afirma sua preferência pelo termo "artes verbais", ainda que nenhuma terminologia seja completamente adequada "e que sintetizar quais exatamente são os fatores constitutivos do que chamaríamos de 'artes verbais ameríndias' de forma mais abrangente seja arriscado" (2017, p. 144-145).

Em razão da complexidade constitutiva e estrutural que permeiam as tradições orais indígenas é que preferimos a adoção do termo "artes verbais" ao invés de "literatura". Como bem coloca Sérgio Medeiros (2009), "[...] diante de um poema indígena, seja ele oral ou escrito, certas concepções tradicionais de literatura e poesia poderão se mostrar tímidas ou limitadas". A predominância das formas eurocêntricas de conhecimento obscureceu outros modos de significação, que se utilizam de complexos sistemas simbólicos para a construção do pensamento, do corpo, da socialidade. Uma verdadeira violência epistêmica. Entretanto, esses modos existem, apesar de ser de conhecimento de alguns poucos leitores mais atentos e interessados nestes tipos de textualidades, fato que é resultado, principalmente, da educação formal brasileira, de base euroamericana. As artes verbais dos povos indígenas entram no pacote dos "conteúdos" desconhecidos, ignorados. E hoje, mesmo estudadas por uma série de pesquisadores mundo afora, estão longe de serem compreendidas em sua profundidade. $\mathrm{O}$ caminho a ser trilhado é longo.

Concordamos com Pedro de Niemeyer Cesarino (2018), estudioso brasileiro das poéticas marubo, o qual afirma que devemos partir do princípio de que há poesia por toda parte. Essas poesias, por sua vez, implicam formas

\footnotetext{
${ }^{29}$ Para uma compreensão mais aprofundada da discussão feita por cada autor, os textos de referência são: NEIVA DE MATOS, C. Escritas indígenas: uma experiência poético-pedagógica. Boitatá, vol. 12, p. 2951, 2011; SÁ, L. Rain Forest Literatures: Amazonian Texts and Latin American Culture. Minneapolis: University of Minnesota Press, 2004; LIBRANDI-ROCHA, M. A carta Guarani-Kaiowá e o direito a uma literatura com terra e das gentes. Estudos da Literatura Brasileira Contemporânea, vol. 44, p. 165-191, 2014; NATALI, M. P. Beyond the Right to Literature. Comparative Literature Studies, vol. 46, n. 1, p. 177-192, 2009.
} 
diversas de experiência, criação, linguagem, pensamento e estética. Implicam, também, o entrelaçamento de símbolos, de formas expressivas, do oral e o escrito, da comunicação entre humanos e não-humanos.

Seja de ordem epistemológica, ontológica ou etiológica, ou mesmo em razão de formas enunciativas e construções sintáticas desestabilizadoras, os desafios a respeito do que é possível ou não ser traduzido são diversos quando o assunto é artes verbais ameríndias. Há dificuldades intersemióticas colocadas pela transposição de códigos, como, por exemplo, a passagem do oral ao escrito ou de sons em palavras. Além dessas dificuldades, como diria o linguista e tradutor indígena Mutuá Mehinako:

\begin{abstract}
A tradução [...] tem sempre equívocos pois o tradutor é sempre vítima das limitações de sua própria língua. Quando traduzimos nossa língua para outra língua, a maior parte da tradução vai apenas aproximar a semântica das palavras e frases, sem jamais encontrar um equivalente exato. No caso dos conceitos, o antropólogo é sempre vítima de seus próprios conceitos ao buscar compreender os conceitos nativos. É um problema grave para a metodologia comparativa. Como fica, aliás, no meu caso em que os conceitos nativos são os meus conceitos e os conceitos antropológicos, que estou estudando, são os conceitos dos outros? Como é possível fazer antropologia em casa quando a antropologia é da casa dos outros? (p. 12-13).
\end{abstract}

Mehinako faz sua reflexão à partir da noção de "equivocidade controlada", cunhada pelo etnólogo Eduardo Viveiros de Castro (2004). Segundo o autor, equivocidades são disjunções comunicativas que ocorrem entre os interlocutores, as quais não podem ser canceladas, mas sim controladas, para que se evite transformar o que é dessemelhante em uma mesma coisa. Em termos de tradução, significa dar voz às diferenças que emergem das equivocidades para se definir algo:

[...] Traduzir é enfatizar ou potencializar a equivocidade, ou seja, é abrir e expandir o espaço que se imagina não existir entre as linguagens conceituais em contato, um espaço que precisamente a equivocidade ocultava. A equivocidade não é o que impede a relação, mas seu fundamento e propulsão: uma diferença de perspectiva. Traduzir é presumir que a equivocidade sempre existe; é comunicar diferenças em vez de silenciar o Outro por presumir uma interpretação única entre o que o Outro e Nós dizemos (VIVEIROS DE CASTRO, 2004, p. 8). 
Nossa intenção com este mapeamento é que ele sirva como um primeiro passo para a exploração coletiva e comunicação dessas diferenças por pesquisadoras/es e tradutoras/es oriundos de diversas áreas (como a Etnologia, a Linguística Antropológica, os Estudos Literários e os Estudos da Tradução) e também por especialistas, mestras/es, professoras/es, escritoras/es e tradutoras/es indígenas, indispensáveis para esta tarefa.

Esperamos ter sido possível oferecer ao leitor uma arqueologia da tradução consistente e abrangente sobre cantos Tupi-Guarani traduzidos para o português nos últimos 50 anos por meio do mapeamento realizado. Como todo mapeamento, sempre haverá lacunas e pontos de atualização. A expectativa é que este trabalho tenha continuidade não apenas no escopo da família linguística Tupi-Guarani, mas também entre outras línguas ameríndias, pois assim será possível obter um mapeamento mais amplo da atividade da tradução de cantos indígenas no Brasil.

\section{Referências}

BAPTISTA, J. V. Roça barroca. São Paulo: Cosac Naify, 2011.

BAPTISTA, J. V.; MIRANDA, L. (Orgs.). Soninho com pios de periquitos

ao fundo. Tradução: Josely Vianna Baptista e Luli Miranda. Ouro Preto: Tipografia de Fundo de Ouro Preto, v. 2, 1996.

BENITES, S. Viver na língua Guarani Nhandewa (mulher falando). Dissertação (Mestrado em Antropologia Social) - Rio de Janeiro: Universidade Federal do Rio de Janeiro/ Museu Nacional, 2018.

CADOGAN, L. Ayvu Rapyta: Textos míticos de los Mbyá-Guarani del Guairá. Revista De Antropologia, v. 1, n. 1, p. 35-42, 1953.

CÂMARA, I. Encontro entre oralidade e memória de uma nação. Revista Continente, Pernambuco, 1 jan. 2012. Disponível em: $<$ https://www.revistacontinente.com.br/edicoes/133/encontro-entreoralidade-e-memoria-de-uma-nacao>. Acesso em 29 jul. 2020.

CESARINO, P. (Org.). Quando a terra deixou de falar: cantos da mitologia Marubo. 1 ed. São Paulo: Editora 34, 2013. 
CHAMORRO, G. Terra madura, yvy araguyje: fundamento da palavra Guarani. Dourados, MS: Editora UFGD, 2008.

CHAMORRO, G. A arte da palavra cantada na etnia Kaiowá. SOCIÉTÉ SUISSE DES AMÉRICANISTES / SCHWEIZERISCHE AMERIKANISTEN - GESELLSCHAFT, v. 73, 2011.

CHESTERMAN, A. O nome e a natureza dos Estudos do Tradutor. Belas Infiéis, v. 3, n. 2, p. 33-42, 2014.

CHEVREL, Yves. Introduction: la retraduction - und kein Ende. In: KAHN, Robert; SETH, Catriona. La retraduction. Rouen: Publications des Universités de Rouen et du Havre, 2010, p. 11-21.

CLASTRES, P. A fala sagrada: mitos e cantos sagrados dos índios Guarani. Tradução: Nícia Adan Bonatti. Campinas: Papirus, 1990.

DIAS, J. P. Concepts and Contests in the Translation of Indigenous Poetics in Brazil. Tusaaji: A Translation Review, v. 4, n. 4, 2015, p. 99-107.

DIAS, J. P. Peles de papel: Caminhos da tradução poética das artes verbais ameríndias. Tese (Doutorado em Estudos Linguisticos e Literários em Inglês) - São Paulo: Universidade de São Paulo, 2017.

D'HULST, L. Why and How to Write Translations Histories? Crop - Edição Especial, v. 6, n. Humanitas FFLCH/USP, p. 21-32, 2001.

D'HULST, L. Translation history. In: Handbook of translation studies. Amsterdam ; Philadelphia: John Benjamins, 2010, p. 397-405.

EQUIPE DE EDIÇÃO DA ENCICLOPÉDIA POVOS INDÍGENAS NO BRASIL. Línguas [s.d.]. (Nota técnica).

FALEIROS, A. Emplumando a grande castanheira. Estudos Avançados, v. 26, n. 76, p. 57-74, dez. 2012.

FALEIROS, A. A noção de retradução nos estudos da tradução: um percurso teórico. Revista Letras Raras, v. 3, n. 2, p. 35-57, 2014.

GAMBIER, Yves. La retraduction: ambiguïtés et défis. In: MONTI, E.; SCHNYDER, P. (Orgs.) Autour de la retraduction. Paris: Orizons, p. 49-67, 2012.

GARCIA, U. F. Karawara: a caça e o mundo dos Awá-Guajá. Tese (Doutorado em Antropologia Social) - São Paulo: Universidade de São Paulo, 2010.

GARCIA, W. G. Nhande Reembypy: Nossas Origens. Araraquara: UNESP - Faculdade de Ciências e Letras. Centro de Estudos Indígenas Miguel A. Menéndez, 2001.

GRÜNBERG, G. et al. Os Kaiabi do Brasil Central: história e etnografia. Tradução: Eugênio G. Wenzel e João Dornstauder. São Paulo: Instituto Socioambiental, 2004. 
HEURICH, G. O. Música, morte e esquecimento na arte verbal Araweté. Tese (Doutorado em Antropologia Social) - Rio de Janeiro: Universidade Federal do Rio de Janeiro/ Museu Nacional, 2015.

HOLMES, J. The Name and Nature of Translation Studies. In: VENUTI, L. (Ed.) The Translation Studies Reader. 2 ed. London: Routledge, Taylor \& Francis Group, 2004. p. 180-192.

JECUPÉ, K. W. Tupã tenondé: a criação do universo, da terra e do homem segundo a tradição oral Guarani. São Paulo: Instituto Arapoty/Editora Fundação Peirópolis, 2001.

LABORATÓRIO DE LINGUAGENS LEETRA. Nheengatu Tapajoara. LEETRA INDÍGENA / UFSCAR, Edição Especial, v. 1, 2015.

LADMIRAL, Jean-René. Nous autres traductions, nous savons maintenant que nous sommes mortelles. In: MONTI, E.; SCHNYDER, P. (Orgs.). Autour de la retraduction. Paris: Orizons, 2012, p. 29-49.

MATOS, C. N. Escritas indígenas: uma experiência poético-pedagógica. Boitatá, v. 12, n. Londrina, p. 29-51, dez. 2011.

MEDEIROS, S. Poética indígena desafia concepções usuais de gênero e leitura. Folha de São Paulo, 18 jan. 2009.

MEHINAKU, M. Tetsualü: pluralismo de línguas e pessoas no Alto Xingu. Dissertação (Mestrado em em Antropologia Social) - Programa de Pós-Graduação em Antropologia Social/Museu Nacional - Universidade Federal do Rio de Janeiro, 2010.

MENEZES BASTOS, R. J. A Festa da Jaguatirica: uma partitura críticointerpretativa. Tese (Doutorado em Antropologia Social) - São Paulo: Universidade de São Paulo, 1989.

MONTARDO, D. L. O. Através do Mbaraka: música e xamanismo Guarani. Tese (Doutorado em Antropologia Social) - São Paulo: Universidade de São Paulo, 2002.

PAULA, E. D. DE. Eventos de fala entre os Apiãwa (Tapirapé) na perspectiva da etnosintaxe: singularidades em textos orais e escritos. Tese (Doutorado em Letras e Linguística) - Goiânia: Universidade Federal do Goiás, 2012.

POTIGUARA, E. Metade cara, metade máscara. São Paulo: Global Editora, 2004.

PRODOCLIN (ED.). Textos produzidos pelos Kawaiwete (anos 2010 e 2011): poemas/músicas e materiais tradicionais Kawaiwete.

PRODOCLIN/Museu do Índio, 2010. Disponível em:

$<$ http://prodoclin.museudoindio.gov.br/images/conteudo/Maxakali/produ tos_pesquisadores/haliti- 
paresi/produtos_pesquisadores/kaiabi_kawaiwete/produtos_pesquisador es/Textos_Kawaiwete_ProDocLin.pdf> PRODOCLIN KAWAIWETE - KAIABI. Yafu: o retorno do chocalho. Rio de Janeiro: FUNAI, 2014.

PUCCI, M.; ALMEIDA, B. (Orgs.). Cantos da Floresta: iniciação ao universo musical indígena. São Paulo: Peirópolis, 2017.

PYM, A. Method in translation history. London New York: Routledge, Taylor \& Francis Group, 1998.

RATTES, K. O Itinerário das Aparições. Ayvu Rapyta e a Palavra de León Cadogan. Tese (Doutorado em Antropologia Social) - Rio de Janeiro: UFRJ, MN, 2014.

RISÉRIO, A. Palavras canibais. Revista USP, n. 13 (maio), p. 26-43, 1992.

RISÉRIO, A. Textos e tribos: poéticas extraocidentais nos trópicos brasileiros. Rio de Janeiro: Imago, 1993.

RODRIGUES, A. D. Línguas brasileiras: para o conhecimento das línguas indígenas. 4. ed. São Paulo: Edições Loyola, 2002.

VIVEIROS DE CASTRO, E. B. Araweté: os deuses canibais. Rio de Janeiro: Zahar: Associação Nacional de Pós Graduação e Pesquisa em Ciências Sociais, 1986.

VIVEIROS DE CASTRO, E. B. Araweté, [s.d.]. (Nota técnica). VIVEIROS DE CASTRO, E. B. Perspectival anthropology and the method of controlled equivocation. Tipití, Journal of the Society for the Anthropology of Lowland South America. Texas, vol. 2, n.․1, p. 3-22, 2004.

\section{Resumo}

O presente artigo é resultado de dois anos de pesquisa, a qual teve como um dos seus objetivos investigar a história da prática da tradução de cantos Tupi-Guarani de 1970 até a atualidade. A pesquisa foi dividida em duas etapas: primeiramente, realizou-se um levantamento para se construir um corpus de traduções, complementado com informações extratextuais relacionadas aos textos e a suas/seus respectivas/os tradutoras/es; a segunda etapa focou na realização de uma "arqueologia da tradução" (D’HULST, 2001, 2010; PYM, 1998) baseada no corpus mencionado com vistas a mapear o cenário da tradução de cantos TupiGuarani dos últimos 50 anos. O mapeamento consistiu na análise quantitativa de um corpus de 233 traduções. Houve uma preponderância significativa de traduções originais (211) sobre retraduções (apenas 11), bem como de traduções não comentadas (186) sobre as comentadas (47). Os textos estão distribuídos em 21 publicações: nove livros, sete teses e 
dissertações, três artigos de periódicos, um material didático e um produto de projeto de documentação linguística. Do total de publicações, 15 apresentam os cantos traduzidos em formato bilíngue (juntamente com o texto em língua indígena), enquanto quatro apresentam apenas as traduções e duas contém textos nos dois formatos. Foram identificados 11 tradutoras/es indígenas (duas mulheres e nove homens) e 17 tradutoras/es não indígenas (nove mulheres e oito homens).

Palavras-chave: Cantos Tupi-Guarani; história da tradução no Brasil; arqueologia da tradução; levantamento; corpus.

\begin{abstract}
This article is a result of two years of research, which had as one of its aims to investigate the history of translation practice of Tupi-Guarani chants from 1970 to the present. The research was divided into two stages: first, a survey was carried out in order to build a corpus of translations supplemented by extratextual information related to the texts and their respective translators; the second stage focused on developing a "translation archaeology" (D'HULST, 2001, 2010; PYM, 1998) based on this corpus in order to map the translations of Tupi-Guarani chants in the last 50 years. The mapping consisted in the quantitative analysis of a corpus composed of 233 translations. There was a significant prevalence of original translations (211) over retranslations (only 11), as well as of translations without commentaries (186) over those with commentaries (47). The texts are distributed throughout 21 publications: nine books, seven thesis and dissertations, three articles, one teaching material, and one document related to a language documentation project. From the total of publications, 15 of them present the chants translated in a bilingual format (along with the original text in the native language), while four present only the translations and two have texts in both formats. Finally, in regard to the translators, 11 are Indigenous (two women and nine men) and 17 are non-Indigenous (nine women and eight men).
\end{abstract}

Keywords: Tupi-Guarani chants; translation history in Brazil; translation archaeology; survey; corpora. 